Representation of visual stimuli in the inferotemporal cortex

Invariance of perception despite modulation

$\mathrm{PhD}$ Thesis

Kaposvári Péter

Supervisor: Gyula Sáry MD PhD

Department of Physiology, University of Szeged

Szeged

2011 


\section{The applicant's relevant publications}

I. SARY, G., KOTELES, K., KAPOSVARI, P., LENTI, L., CSIFCSAK, G., FRANKO, E., BENEDEK, G., TOMPA, T., (2008) The representation of Kanizsa illusory contours in the monkey inferior temporal cortex, Eur. J. Neurosci. 2008. Nov. ;28. (10):2137. -46., 28, 2137-2146.

II. KAPOSVÁRI P. CSIBRI, G. CSETE, T. TOMPA AND GY. SÁRY, Auditory modulation of the inferior temporal cortex neurons in rhesus monkey, Physiological Research (in press)

Posters

I. GY. SÁRY, T. TOMPA, K. KÖTELES, P. KAPOSVÁRI AND GY. BENEDEK, Beyond physical boundaries: coding of two types of illusory contours in the macaque inferotemporal cortex, MITT 2008

II. GY. SÁRY, T. TOMPA, P. KAPOSVÁRI AND GY. BENEDEK, Beyond physical boundaries: coding of abutting-line and Kanizsa-typeillusory contours in the monkey inferotemporal cortex, MET 2008

III. P. KAPOSVÁRI, P. CSIBRI, G. CSETE, T. TOMPA AND GY. SÁRY, Sounds modulate neurons in the visual cortex of the monkey, Belgrád, International symposium, One hundred years of Ivan Djaja's 2010

IV. P. KAPOSVÁRI, P. CSIBRI, G. CSETE, T. TOMPA AND GY. SÁRY, Sounds modulate neurons in the visual cortex of the monkey, Mitt 2011

Presentations

I. KAPOSVÁRI PÉTER, CSETE GERGŐ, CSIBRI PÉTER, TOMPA TAMÁS, SÁRY GYULA, Auditorikus hatások a látórendszerben (Bimodális integráció a majom inferotemporális kérgében), Látás szimpózium 2010 (presentation)

\section{Other publications}

I. TAMÁS TOMPA, PÉTER KAPOSVÁRI, GYÖRGY BENEDEK, GYULA SÁRY, Intact versus contour deleted stimuli in the inferior temporal cortex - traces of a holistic type of representation, MITT 2009 (poster)

II. PÉTER KAPOSVÁRI, GYULA SÁRY, GYÖRGY BENEDEK, TAMÁS TOMPA, Edges and surfaces in the inferior temporal cortex of the macaque - an electrophysiological study, MITT 2009 (poster)

III. KAPOSVÁRI PÉTER, SÁRY GYULA, BENEDEK GYÖRGY, TOMPA TAMÁS, Képben a vonal (A megjelenítés módjainak hatása a makákó inferotemporális kérgi neuronok válaszaira), Látás szimpózium 2008 (presentation) 


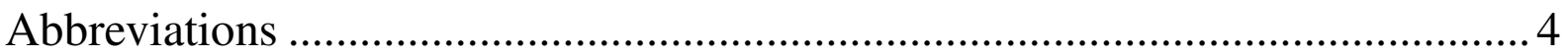

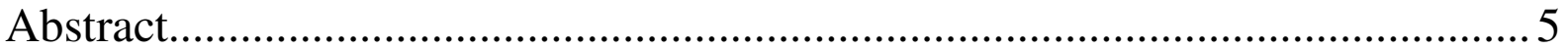

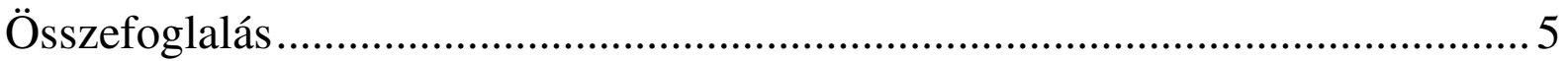

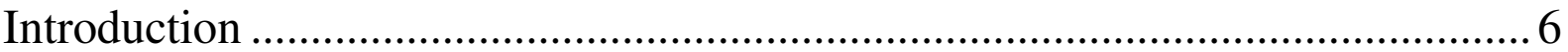

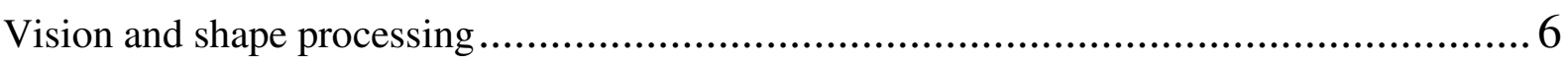

Alternative functional methods from an experimental viewpoint ...................................... 8

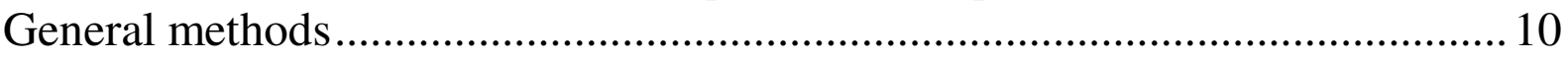

Experiment I.: The representation of Kanizsa type illusory contours in the monkey inferior temporal cortex .................................................................... 15

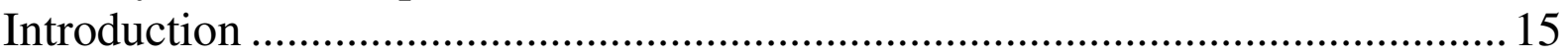

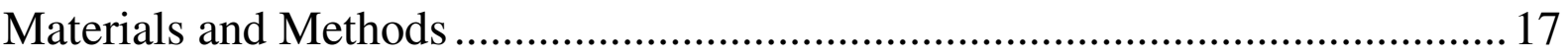

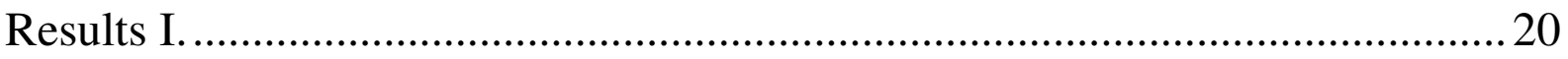

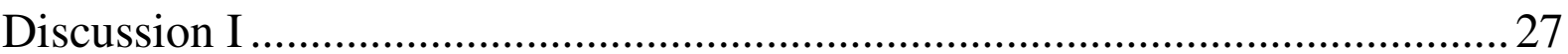

Experiment II: Auditory modulation of the inferior temporal cortex neurons in

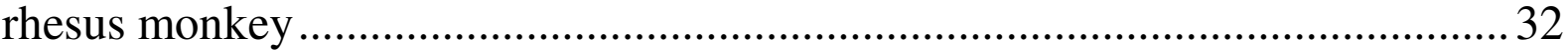

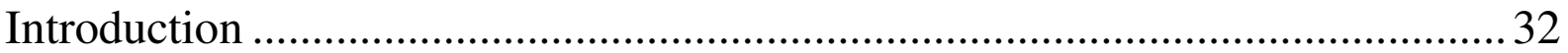

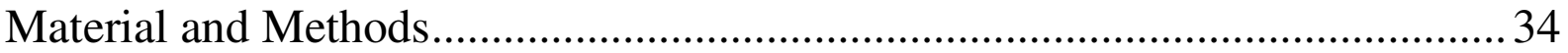

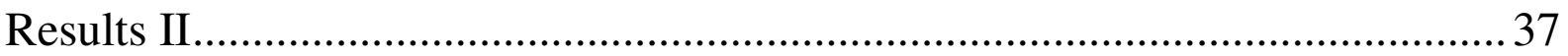

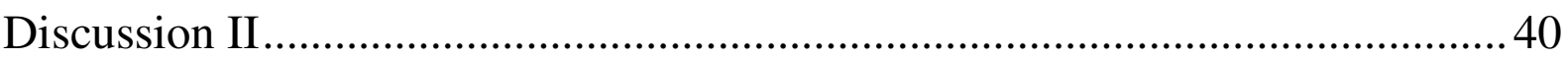

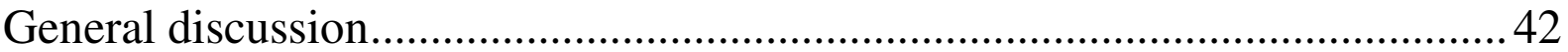

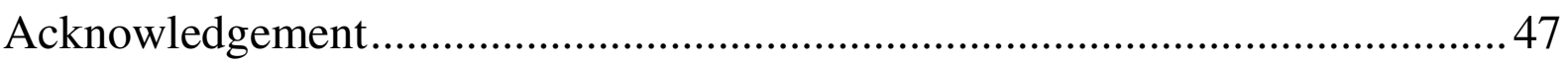

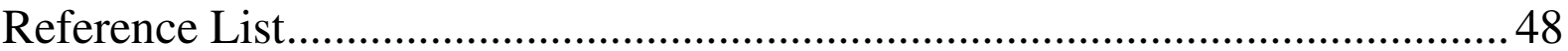




\section{Abbreviations}

AP: action potentials

AUDIO: auditory stimuli

AUDIOVIS: bimodal stimuli

CRT: control

FP: fixation spot

FW: fixation window

IC: subjective contours

ITC: inferotemporal cortex

KIC: Kanizsa IC

LD: line drawing

LFP: local field potential

LGN: lateral geniculate nucleus

MST: medial superior temporal area

PSTH: peristimulus time histogram

SC: superior colliculus

SI: selectivity index

SIL: silhouette

STS: superior temporal sulcus

TE: anterior part of the inferotemporal cortex

TEO: posterior part of the inferotemporal cortex

V1: primary visual cortex

V2: secondary visual area

VIS: visual stimuli 


\begin{abstract}
Invariant sensory processing enables the sense of locality among the information units of the surroundings, but at the same time it also needs to be variable to adapt to a continuously changing environment. Robust coding guarantees the invariability and it also makes the sensory system able to learn by plasticity. Current research based on the investigation of the inferior temporal cortex of the macaque monkey in our laboratory supports the same view. Most of the cells in this brain area are selective for the shape of the visual images. This feature was strongly consistent despite the change of the stimuli parameters, while some changes could cause modulation of response attributes, such as firing rate or latency. This thesis reports on one hand about the processing of Kanizsa type of illusory contours in the inferotemporal cortex (robustness) and, on the other hand, about the changes in neural responses caused by auditory stimulation in this visual area (plasticity).
\end{abstract}

\title{
Összefoglalás
}

Az érzékelő folyamatok állandósága miatt lehetséges a bejövő információ egységei közötti tájékozódás, ugyanakkor ez szükséges az állandóan változó környezethez való adaptációhoz is. Az információ robusztus kódolása garantálja az állandóságot, és ugyanez teszi lehetővé a szenzoros rendszer plaszticitását, a tanulást. A makákó inferotemporális kérgének vizsgálatából származó eredményeink is ezt a nézetet támasztják alá. E terület sejtjeinek nagy része szeletíven válaszol vizuális stimulusokra. Ez a jelenség a képek fizikai paramétereinek változtatása mellett is konzisztens marad, míg más jellegű változtatások modulációt okozhatnak a sejtválaszok bizonyos jellegeiben, mint például a tüzelési rátában és a latenciában. Ez a tézis egyrészt beszámol arról, hogy hogyan dolgozza fel a Kanizsa típusú illuzórikus kontúrokat az inferotemporális kéreg (robusztusság), másrészt az ismerteti az auditorikus stimulusok által okozott modulációt ezen a vizuális területen (plaszticitás). 


\section{Introduction}

The concept to approach the sensory system as a structure made of separate entities is not correct. There is no sensory information which does not affect the ongoing processing of information and the output, even if it is not manifested immediately in a reaction, or in a measurable or visible output. Perception, representation and action (i.e. the activity of the motor-system or learning) can not be divided, they work in the same system which has to adapt to the environment holistically. Investigating the input of this system suggests its viewing as separated sensory parts, including vision.

\section{Vision and shape processing}

Vision

The reflected photons from the surface of objects pass into the eye where the light signal is translated to action potentials by the cells of the retina. The information passes through the lateral geniculate nucleus to the primary visual cortex (V1). There is an alternative, parallel pathway through the superior colliculus to the extrastriate visual cortex and the basal ganglia. This extra geniculo-(extra)striatal pathway uses visual information mostly for the eye movement and for the analysis and performance of fast motion. According to a current hypothesis, the pathway from V1 diverges to a dorsal and ventral stream. The first is responsible for the processing of spatial or "where" information while the ventral part codes the shape, texture, and colour features of the visual information (Ungerleider \& Mishkin 1982). In a recent concept, the dorsal pathway processes the motion information and cooperates with the subcortical visual regions (Goodale \& Milner 1992) (FIG 1).

\section{Shape processing, ventral stream}

In the ventral stream the processed visual information becomes more and more complex, from the simple orientation discrimination in V1, (Hubel \& Wiesel 1962) to the complex shape selectivity in the monkey inferotemporal cortex (ITC) (Gross et al. 1969). It has to be mentioned that this pathway is not completely separated from the other, the dorsal pathway (Merigan \& Maunsell 1993). The ITC is the last stage of the ventral visual stream. It almost overlaps Brodmann areas 20 and 21. It is divided into posterior (TEO) and anterior (TE) areas (von Bonin \& Bailey 1947) and later into more subdivisions (Baylis et al. 1987). The TE 
receives input indirectly from V1, the secondary visual area (V2), and V4 and from the area temporalis media superior (MST) through the TEO and directly from the V1 and STP. The principal projections of the TE go to parahippocampal, perirhinal, entorhinal cortices, the hippocampus and the amygdale.

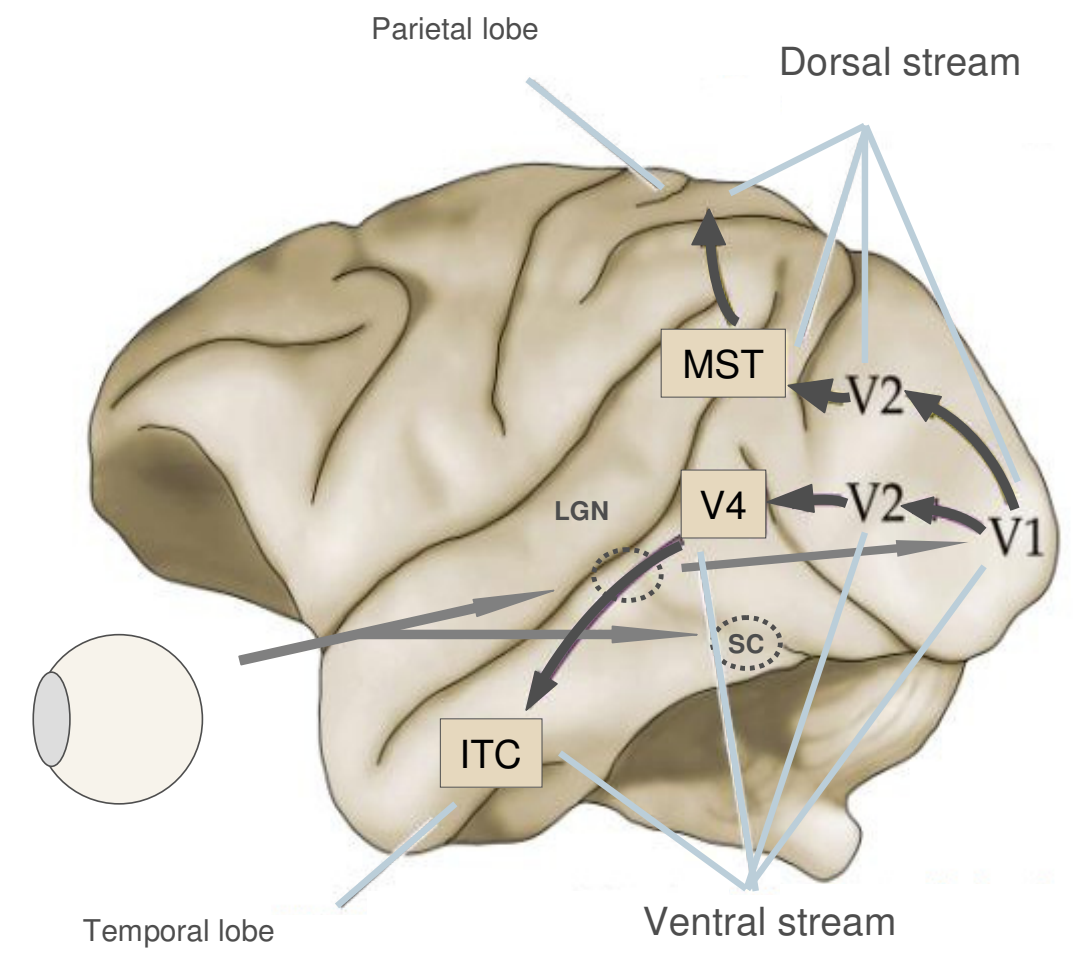

FIG 1: Visual pathways in the monkey brain. The extra geniculo-(extra)striatal pathway receives signals through the superior colliculus to the extrastriate visual cortex and the basal ganglia. The dorsal stream is responsible for the processing of "where" information while the ventral part codes the shape, texture and colour of the visual objects. Lateral geniculate nucleus (LGN), superior colliculus (SC), primary visual cortex (V1), secondary visual area (V2), temporalis media superior (MST), inferotemporal cortex (ITC).

The information and cellular projections converge in the ventral stream, thus the receptive field of the cells increases as we move from V1 towards ITC. It becomes binocular and up to 70 degrees large in area TE. In this area, more than $85 \%$ of the cells responds for elaborate visual stimuli in either an excitatory or an inhibitory way (Rousselet et al. 2004; Desimone et al. 1984). The main feature of the ITC is shape selectivity, or shape preference (FIG. 2.). The preferred stimuli for these neurons are complex coloured images; they trigger the biggest 
response for this kind of stimulus. The baseline activity of the cells on average is $8-10 \mathrm{~Hz}$. The responses could go up in some cases to $80 \mathrm{~Hz}$.
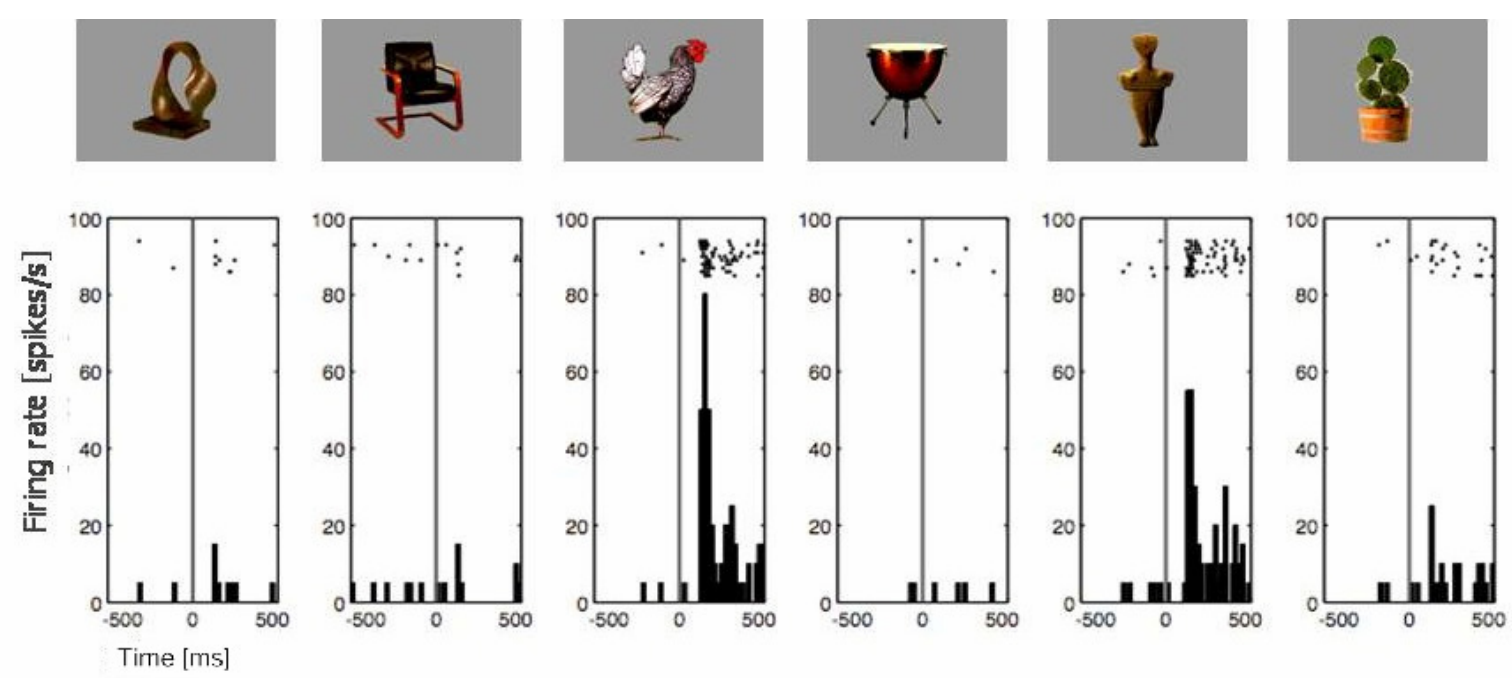

FIG 2: The cells in ITC give response selectively for different visual stimuli. Axis Y shows the level of cellular activity, axis $\mathrm{X}$ shows time. There is baseline activity before 0 (stimulus onset time). The responses are significant for stimulus 3. and 5. from 0 to $500 \mathrm{~ms}$. Peristimulus time histograms show the mean firing rates after ten presentations of the stimuli.

\section{Alternative functional methods from an experimental viewpoint}

This thesis is about experiments based on single cell recordings, but there are several functional tools to investigate a brain area as well. Each method has its advantages and disadvantages. The critical features of the methods are the temporal and spatial resolution, sensitivity for the intensity differences and source of evoked response.

Some methods rely on the observation that activity increases in a certain brain area followed by increased blood flow within a few seconds (fMRI, SPECT and PET). Others use the task related changes in electrical activity of the brain (EP). The source of fMRI signal is the change in the blood oxygenation level (BOLD: blood-oxygen-level dependent). PET (positron emission tomography), SPECT (single photon emission computer tomography) techniques follow the blood flow and the metabolism in the tissue. Each method has a good spatial resolution (in the mm range), but neither the temporal resolution, nor the sensitivity for the small intensity changes is satisfying. Recording electrical brain activity from the scalp is 
called evoked potential (EP). The electrodes receive electrical signals from a large area of the brain surface, from the cortical parts parallel with the surface, i.e., mostly from the gyri. The signal source of the MEG (magneto encephalography), which collects electromagnetic activity from the scalp, is different from that of EEG's. It receives input from the cortical areas lying perpendicular to the skull surface, i.e., sulci and the subcortical brain areas. Both techniques are sensitive for the response intensity and have a good temporal resolution, however, the spatial resolution is poor.

These non invasive techniques are becoming widespread for experiments on human subjects. By using them simultaneously we can get a more complete picture about the functions of the brain areas. If we want to be more accurate, we must go deeper. Using invasive techniques is limited in the human brain, it is allowed only during some clinical interventions. Animal experiments offer an alternative solution.

Another electrophysiological technique is ECoG (Electrocorticography), where electrodes are placed directly on the brain surface. This method gives better spatial resolution than the EEG, and its temporal resolution is maintained, but we get information only from a small brain area, provided the particular cortical area is surgically accessible.

The different kinds of optical imaging also have good spatial and temporal resolutions, but the available cortex is limited.

Single cell recording gives exact information about the single neuron's electrical activity, i.e., action potentials (AP). Temporal resolution is good - in fact it is the best theoretically possible. Parallel LFP (Local field potential) recording is possible in a frequency band between $0-200 \mathrm{~Hz}$. The LFP is considered as the sum of inputs, while action potentials represent the output of the neurons.

This brief and far not complete overview of the techniques shows that invasive animal experiments gave irreparable from other sources results about brain functions. 


\section{General methods}

Subjects:

Three adult monkeys (Macaca mulatta $(6.5-8 \mathrm{~kg}$ at the time of the experiments, one female and two males), two for each experiments were used as subjects. We used operant conditioning with a controlled water access paradigm, i.e., the animals had access to water or fruit juice and consumed their daily need only during the recording session. At weekends they had fruits and vegetables ad libitum. The weight of the animals was checked regularly and was kept at $90 \%$ of the normal body-weight. Special attention was paid to the animals' general condition, with frequent checks of their fur and excrement. They had a resting period for one month every 2-3 months.

First, in general anaesthesia, under aseptic conditions, an eye-coil was implanted under the conjunctiva (Judge et al. 1980), a headpost and a recording chamber was mounted on top of the skull (FIG.3.). MRI images from the brain and stereotaxic coordinates helped to find the right location, from which the ITC could be reached. In most cases the chambers were centred at AP 16-17, Lat 22-23. During the recording period animals usually worked 5 days a week, 3 hours a day. At the end of the experiments animals were sacrificed with an overdose of barbiturate, perfused with fixative and the brain was removed. Frozen sections having a thickness of 60-100 $\mu \mathrm{m}$ were ideal to localize electrode tracks.

All procedures conformed to the guidelines of the NIH for the care and use of laboratory animals and were approved by the Ethical Committee of the University of Szeged.

\section{Apparatus:}

During the recording sessions the monkey sat in a custom-made primate chair with its head fixed. A 17-inch monitor (Philips Brilliance 17A, , refresh rate $=74 \mathrm{~Hz}$, resolution $=800 \times 600$ pixels) was placed in front of the animal at $57 \mathrm{~cm}$ from the eye.

A PC recorded eye movements (200 Hz sampling rate), based on the movement of the eye in a two dimensional magnetic field, which in turn induced flux in the implanted eye coil. There were two pairs of coils around the chair. One is at its two sides, the other one is at its bottom and top. The magnetic field has two frequencies in two dimensions $(80 \mathrm{kHz}$ and $96 \mathrm{kHz}$, respectively), thus the induced flux had two frequencies as well. They were separated on-line 
by furrier transformation (Angle-Meter, 040401, Primelec, D. Florin, Switzerland). Other computers presented stimuli and collected electrophysiological data.

Sterile tungsten electrodes (FHC, parylene-coated with an impedance of 1.0-4.0 M $\Omega$ ), held by a Narishige hydraulic microdrive, were used for single-cell recordings. Signals were amplified, frequency-filtered and fed into the recording PC, audio monitor and oscilloscope. Single-cell discrimination was performed with an amplitude window discriminator. The background luminance in the experimental room was kept low at a constant level of $<1$ $\mathrm{cd} / \mathrm{m}^{2}$.

\section{Recording site}

In cases, where the histological verification of the recording site was not available, we relied on some evidence proving that the electrode positioning was right into the TE. The recorded neurons showed responses typical for this region (response latency, stimulus selectivity).
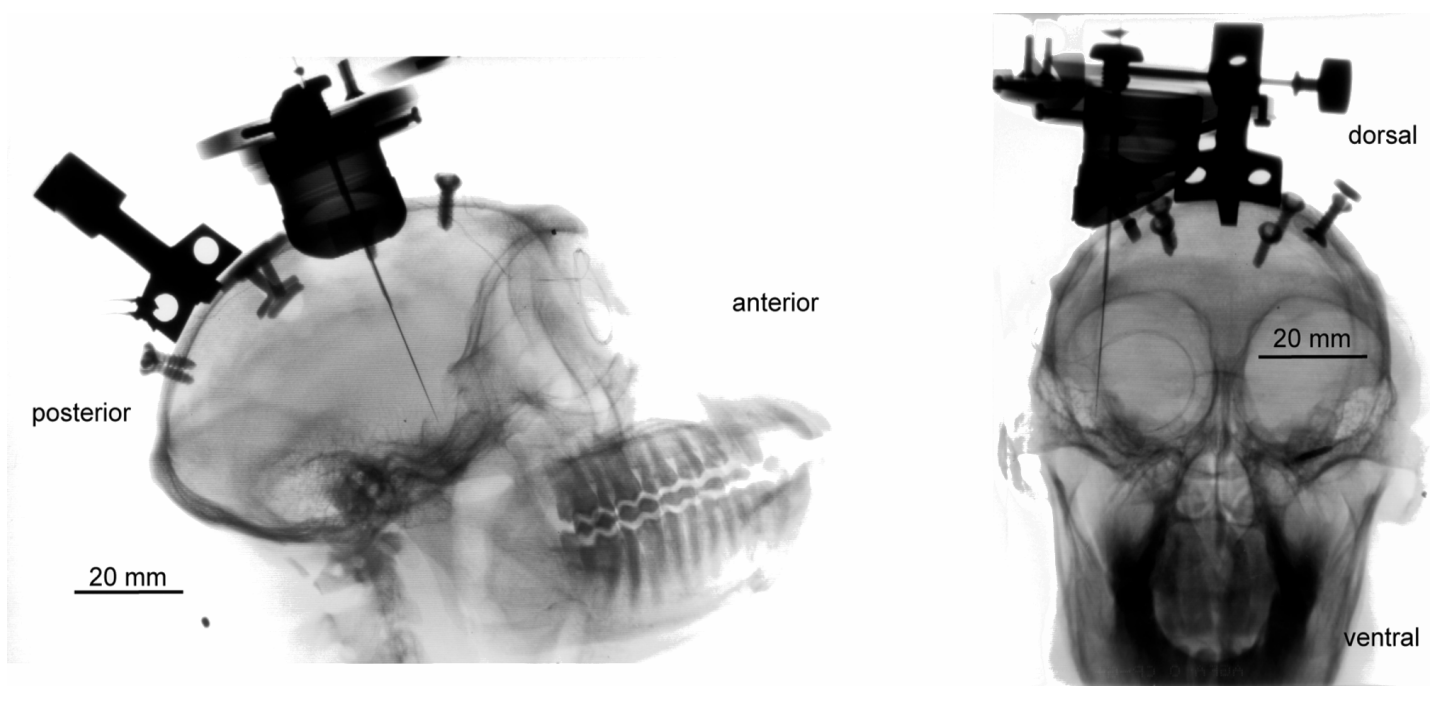

FIG 3: X ray images from one of the monkeys. Lateral view from the skull showing the surgical screws, headpost, recording chamber and eye coil. The electrode points to area TE of the inferotemporal cortex. The frontal view of the skull shows the electrode lowered at app. lateral $22 \mathrm{~mm}$ from the midline.

The recording chamber was mounted on the basis of the atlas of the monkey brain (Paxinos et al. 1999), and on previous MRI. On the bases of measures obtained from the MRI images, the stereotaxic atlas coordinates were corrected if necessary. The centre of the recording chamber 
was situated $17 \mathrm{~mm}$ anterior to the auditory meatus and $22 \mathrm{~mm}$ lateral to the midline on the skull. Our recordings were made in the appropriate area, which was confirmed by reaching the subarachnoidal space at the end of the recording session. Neuronal activity was collected from two cortical regions, before the electrode reached the bone: the lower bank of the superior temporal sulcus (STS), and the bottom of the TE. They are known as TEa and TE1 (Baylis et al. 1987). We clearly recognized the white matter between these two parts of the TE, and also the gap between the two banks of the STS. Finally, X-ray images made in the coronal and sagittal planes in one monkey with an in situ electrode showed our electrode positioned into area TE of the ITC (FIG.3.).

\section{Training}

First, the animals had to get used to sitting in a primate chair with the head unfixed. Later we fixed the head by the headpost. The animals spent more and more time (up to 3 hours) in the chair day by day (FIG. 4.).

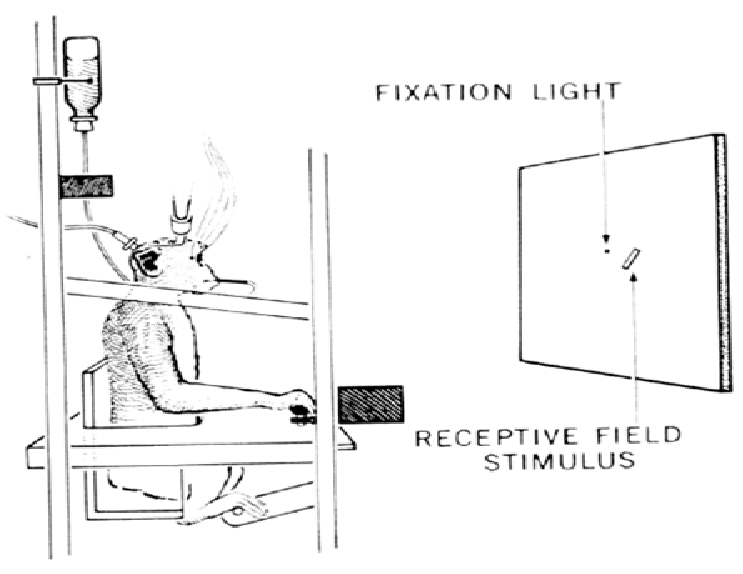

FIG 4: Monkey in the registration set up (Wurtz 1969)

Our monkeys had to learn a fixation task to ensure that the presented visual stimuli always fall on the same retinal location. First, the fixation point was presented at regular intervals on the monitor for several seconds. While controlling the eye movements, the monkey was rewarded when its gaze was in the fixation window (FW), whose size was controlled by the experimenter. At the beginning of the training the FW was set as large as the monitor. Thus, when the monkey was glancing on the monitor, it was rewarded immediately. Then we made 
the FW smaller and smaller until we reached the standard size of $1 \times 1$ degree. The next step was to make the fixation time longer, up to the desired 1-1.5 s. Our experience showed that longer fixation periods automatically resulted in better fixation precision. After the animals reached a performance over $90 \%$ with these parameters, we started recording from the IT cortex (area TE). It took the animals on average about one month to learn this simple task by operant conditioning.

Stimulus presentation

A simple fixation paradigm was used during the single-cell recording sessions. Initially, the monitor screen was black. A trial started with the presentation of the fixation spot (FP, radius: 3 pixels). If the animal foveated the FP, the background pattern was presented in the centre of the screen and then the stimulus appeared. One trial took 1000-1200 ms. The background on the screen also served for the estimation of the baseline activity of the recorded single units. After some time the stimuli were presented in a semi random fashion. Animals were rewarded for maintaining their gaze within a 1 x 1 degree square window until the stimulus offset. If they left the fixation window earlier than the stimulus offset, the trial was considered 'aborted', reward was not given and the trial was excluded from further analysis.

The inter-trial interval was set usually to $1000 \mathrm{~ms}$.

Single-cell recording protocol

We searched for single cells by presenting a set of "hunting" stimuli. Once a cell was isolated and found to be responsive to at least one of the stimuli, it was tested further with the test stimulus. Thus, we investigated a subpopulation of the TE neurons. To test stimulus selectivity, we ran tests by presenting selected stimuli (6-10), about half of which elicited larger firing rates from the particular neuron and the other half was less effective stimuli. Moreover, we presented different variations of these stimuli depending on the experimental needs. 
Data analysis

Data were processed off-line using custom made programs, MATLAB (MathWorks) and Statistica (Statsoft. Inc.) package. Net responses were calculated by the trial-wise subtraction of the neural activity during the fixation period from the activity triggered by the stimulus. ANOVA was used to check for differences between conditions and between the tuning curves, and the Wilcoxon matched t-test was used to compare firing rates and latency values. Tests were classified as significant if the corresponding type I error was $<0.05$.

To determine the responsiveness of the neurons tests were performed on the neural data with the time period of the firing activity before vs. after stimulus onset.

The response onset latency was calculated by using the "Poisson spike train analysis" (Hanes et al. 1995), which was a modified version of an earlier method (Legendy \& Salcman 1985). For each trial, we took the beginning of the first activation phase after the stimulus onset. This was corrected by a weighted sum of the times of occurrence of the spikes preceding stimulus onset (but still after stimulus presentation). The reciprocals of the numbers of spikes after the given spike were used as weights.

$$
t_{\text {lat }}=t_{\text {burst } 1}-\sum_{i=1}^{n} \frac{t_{i}}{N-i}
$$

where $t_{\text {lat }}$ is the latency, $t_{\text {burst }}$ is the beginning of the first activation, $t_{i}$ is the arrival time of spikes between the stimulus onset and $t_{\text {burst }}, n$ is the number of spikes between the stimulus onset and $t_{\text {burstl }}$, and $N$ is the number of spikes after the stimulus onset.

The latency values for a given cell and each stimulus were the trial-wise averages of the values described above. This method provided latencies consistent with the peristimulus time histogram (PSTH).

To determine the selectivity of the neurons, for each neuron and condition, the objects were first ranked according to their net responses in one condition, this way a tuning curve was constructed. This showed the differences in the response strength given to a particular stimulus set in a particular neuron. Second, the average firing rate was calculated separately for each unit and each condition as a function of the stimulus rank. Neurons that exhibited an interaction effect of the two factors (stimulus rank and the neural activity) were considered to be shape selective. 


\section{Experiment I.: The representation of Kanizsa type illusory contours in the monkey inferior temporal cortex}

\section{Introduction}

The easiest way to separate the object from the background is based on contours, which are caused by differences in physical parameters (such as colour, luminance, motion, etc.). Perceived boundaries without physical differences between shape and background are called illusory or subjective contours (IC). They show that the perception is an active process; the sensory system gets the information in a flexible way. Thus, the investigation of these kinds of contour's processing can reveal mechanisms of perceptual organization, e.g., mechanisms of figure-ground segregation or contour integration.

The first result from early stages of the monkey visual pathway show that, in contrast to real contours, responses were found only in V2 (area 18), but not in V1 (area 17) during the presentation of IC-s (von der Heydt et al. 1984).

An experiment with orientation discrimination task supports that there are two different ways of processing: one is only for real contour perception, and the other one is for both the real and also for the illusory contour (Vogels \& Orban 1987). A part of this theory was based on the previous finding, but later it was found that activation could be evoked by IC in area 17 in monkey and also in cat (Sheth et al. 1996; Grosof et al. 1993; Peterhans \& von der Heydt 1991). However, these responses were weaker than for real contours and IC triggered activity pattern differed from that elicited by real contours (Ramsden et al. 2001). The missing response of V1 in the experiment of von der Heydt et al might have been caused by the different grating frequency of the IC stimulus. In the early stages of the monkey visual pathway, after the IC stimulus onset, the first responses were found in superficial V2 (Lee \& Nguyen 2001). The average latency of these responses is $70 \mathrm{~ms}$. The cell responses of the deeper layers in V2 have $95 \mathrm{~ms}$ long latency. Next, activity was found in superficial V1, these cells respond at 100ms. The latencies in the deep layers of V1 are between 125-190 ms. This is much larger than the latency for real contour, which is $45 \mathrm{~ms}$. Moreover, the first response in V2 also has longer latency (by $25 \mathrm{~ms}$ ) for IC than for real contour. These results suggest that the early stage of visual system plays an important role in the processing of IC stimulus. 
Much less data is available regarding the role in IC computation at the hierarchically highest levels. Findings involving results from imaging studies of the human brain (Larsson et al. 1999; Mendola et al. 1999) support the idea that high-order other visual areas might play an important role in processing ICs. The lesion of the analogous with V4 and inferotemporal cortex in monkey do not give a clear picture about how much IC perception is relying on the function of these areas (Huxlin et al. 2000; Merigan 1996). It is also possible that these areas just receive an already completed representation of the contour. The results of a psychophysical study show that higher order areas are needed when the contours are made of subjective (illusory) borders (Imber et al. 2005).

The IT cortex is a cortical area believed to be essential for shape and object vision (Dean 1976). Thus, it would be interesting to know how neurons thought to be responsible for the perception of shapes participate in the processing of IC.

Recently it has been shown how cells react to ICs based on abutting gratings pattern (Vogels \& Orban 1987) in the monkey ITC (Sary et al. 2007). In the present experiment we tested whether ITC neurons respond to shapes defined by another type of illusory contours, the ones of the Kanizsa type (Kanizsa 1976) (FIG. 5.).
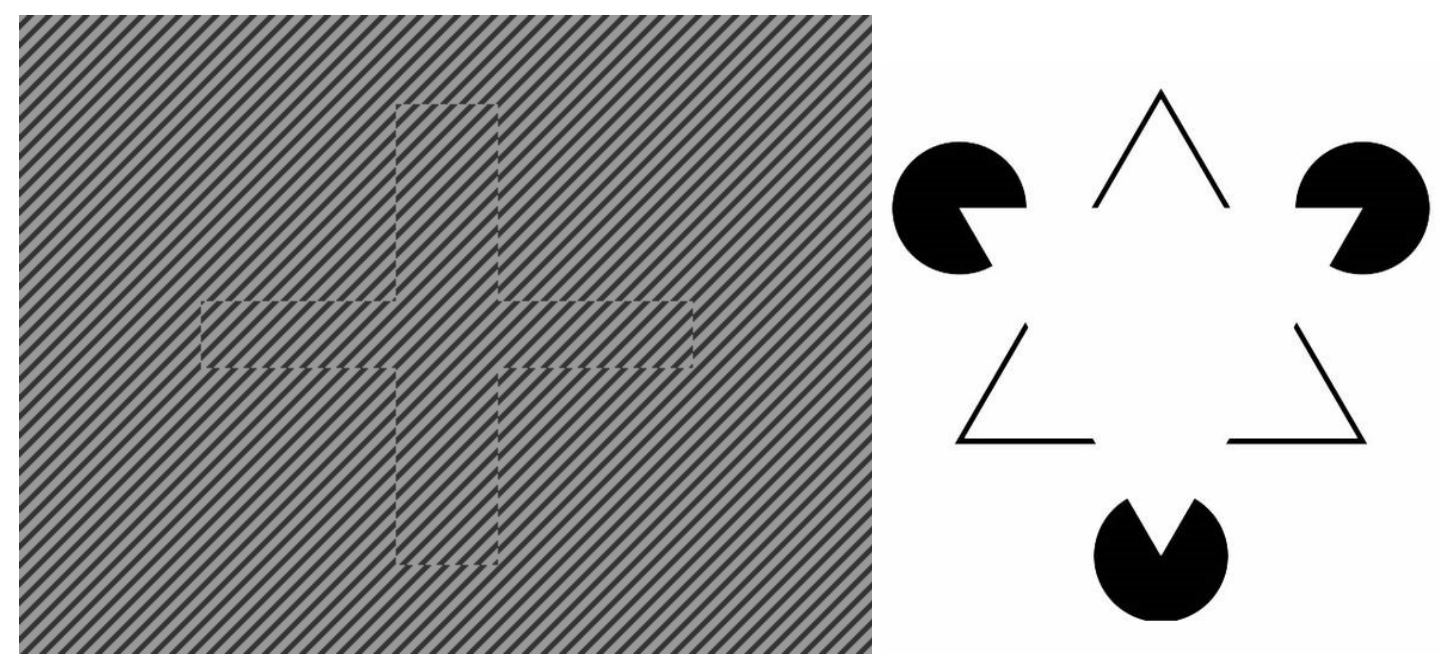

FIG. 5: Two types of illusory shapes: abutting gratings pattern (left), Kanizsa illusory shape (right). 


\section{Materials and Methods}

\section{Stimuli}

The stimulus set contained four different conditions: line drawing (LD), silhouette (SIL), Kanizsa IC (KIC) and control (CTR) images (FIG. 6.). Each was derived from the illusory shapes. We used 9 black discs with white background $\left(30 \mathrm{deg}^{2}\right.$, luminance $\left.=8 \mathrm{~cd} / \mathrm{m}^{2}\right)$ as basic stimulus to test the baseline activity. They functioned as inducers when the shapes were presented on it in the Kanizsa condition. There were 20 stimuli in the different conditions.

Kanizsa type shapes with illusory contours were produced by cutting the overlapping parts of the shape from the discs. This way we generated perceived edges between the "pacmen" producing different Kanizsa type images.

The LD square shape had $18 \mathrm{deg}^{2}$ size, and its luminance with the inducers was $23 \mathrm{~cd} / \mathrm{m}^{2}$.

The mean luminance was $16 \mathrm{~cd} / \mathrm{m}^{2}$ in SIL condition, which was made by filling up the area between the inducers with homogenous grey (contrast: 68\%) colour.

In the control condition, the "pacmen" from the IC condition were rotated out from their original position (Brodeur et al. 2006), thus not producing KIC any longer whilst retaining the geometrical details of the inducers.

The line drawing condition was used to "hunt for" and isolate the cells.
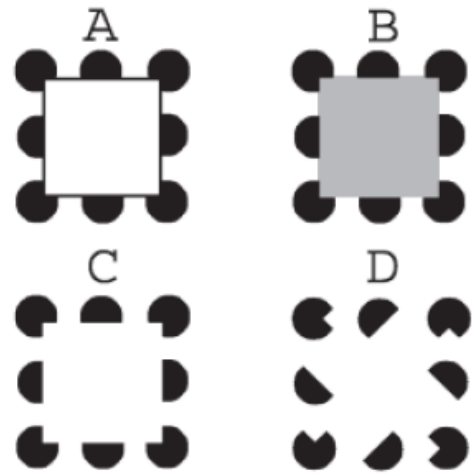
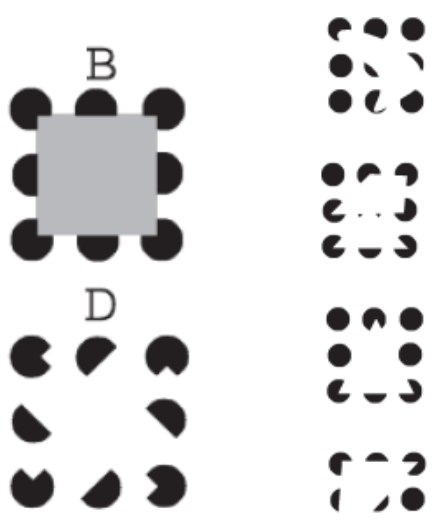
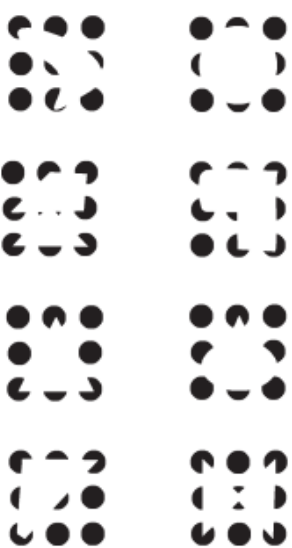
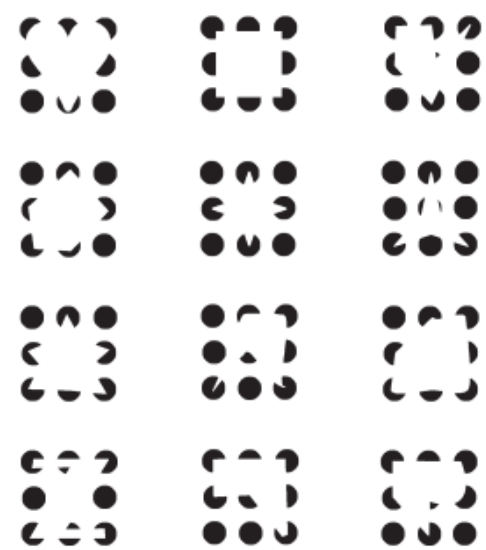

FIG 6: 4 different conditions were used in this experiment: (A) shape with real contour, (B) silhouette, (C) Kanizsa illusory shape, (D) control. Set of the illusory stimulus (right). 


\section{Behavioural test}

The twenty LDs were divided into two groups and 10 stimulus were associated with a leftside saccade while the other 10 were associated with a right-side saccade (Sary et al. 2006). The offset of the LD stimuli was followed by the appearance of two small red target spots on both edges of the screen. On the basis of the previous training the animal had to decide which side to make the saccade to, and correct responses were rewarded with drops of water or fruit juice. Once the animal reached an average performance of $90 \%$ correct with LDs, stimuli were intermixed using SILs and KICs. During these trials the animal was rewarded for the SILs or KICs regardless of the responses it gave.

Stimulus sequence and single-cell recording protocol

A trial started with the onset of FP (luminance $\left.=5.5 \mathrm{~cd} / \mathrm{m}^{2}\right)$ on the computer screen on dark background. If the animal fixated long enough, a white background was presented to level the baseline activity. After $300 \mathrm{~ms}$ nine black discs (the inducers without the notches) appeared for $400 \mathrm{~ms}$ followed by the stimuli themselves for $500 \mathrm{~ms}$ (FIG 7).

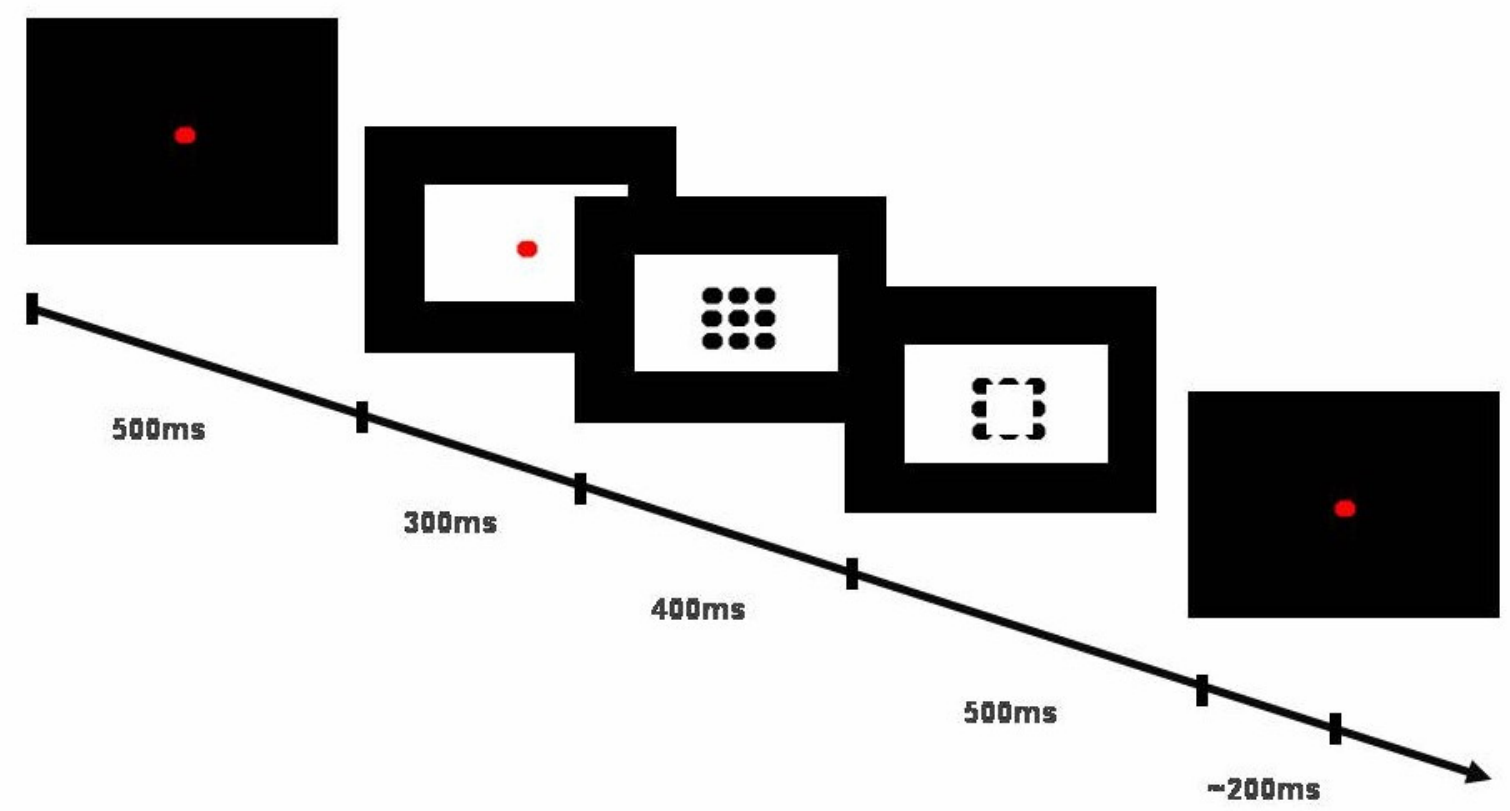

FIG 7: Stimulus presentation started with the fixation point (FP). When the monkey was fixating, a white background appeared behind the FP (300ms). It was followed by the black inducers $(400 \mathrm{~ms})$. They were used for baseline calculation. Then the stimulus was presented for $500 \mathrm{~ms}$. If the monkey was watching the monitor during the trial, it was rewarded. 
First, every stimulus from the "hunting" condition was presented at least 5 times in a pseudorandom sequence. The LD was the ,hunting” condition in this case. Effectivity of the stimulus (the magnitude of the cellular responses) was estimated upon inspection of the PSTH and auditory feedback online. The visual inspection of the PSTH is a common method to decide the effectiveness of a stimulus before the actual statistical evaluation (Kovacs et al. 2003; Tamura \& Tanaka 2001; DiCarlo \& Maunsell 2000). This selection method was also confirmed by offline analysis. Once a cell was found to be responsive to at least one of the stimuli, we ran tests using six shapes: three eliciting the largest firing rates from a particular neuron ("effective stimuli"), and three, which triggered only a moderate response, or no response at all ("non-effective stimuli"). Each of the six shapes was then presented in the different stimulus conditions (LD, KIC, SIL and CTR) in semi randomized, interleaved fashion, at least 10 times.

Data analysis

We analysed spike counts in two $300 \mathrm{~ms}$ time windows off-line. The first window was set from $-300 \mathrm{~ms}$ to $0 \mathrm{~ms}(0=$ stimulus onset time $)$ with the black discs inducers serving for the estimation of the baseline activity, and a second was used to calculate the stimulus-evoked response (100-400 ms).

To make a statistical comparison between the net response levels, we took the responses given to the most effective stimulus in every condition. This way, neuronal activities of the cells in response to the best (quasi optimal) images from our stimulus set in the different conditions could be compared.

The latency was calculated by using the "Poisson spike train analysis" only in case the cell had a significant response to at least one of the stimuli.

To assess the stimulus selectivity of the cells, tuning curves were constructed as follows: for each neuron and condition, first, the six selected stimuli according to their absolute net responses in one condition were ranked and then this sequence was followed in the other conditions. 


\section{Results I.}

Behavioural test

After the animal had reached a performance of $90 \%$ correct with the LDs, SILs and KICs were intermixed with the LDs. In this mixed condition, the performances were (mean +SEM) LDs, 90.05 +- 2.2; SILs, 90.3 +- 2.1; KICs, 86.7 +- 2.8; and CTR, 59.1 +- 4.0 correct. An ANOVA and post hoc test (Fiser) revealed that the performances for LDs, SILs and KICs did not differ, and the animal performed much better for these conditions than for CTR, for which the performance was slightly above chance (ANOVA, F=26.94, P <0.001).

\section{Single cell recording}

The responses of 129 cells from the two monkeys tested for LD, KIC, SIL and CTR were analysed. There was no difference between the results of the two animals so the data were pooled. From these cells 99 (76.7\%) were found to be selective for the KIC (ANOVA). The following results were derived from these cells.

\section{Responsiveness and selectivity}

It has to be mentioned, that there were neurones which gave significant responses only to the LD, as seen on the figure (FIG. 8.). This PSTHs shows two neurons isolated from the IT. The neurons also showed selectivity for the stimuli: the cell in the upper panel responded only to the $1^{\text {st }}$ stimulus (ANOVA in the LD condition: $\mathrm{F}=3.96, \mathrm{p}=0.004$ ), and the responses of the cell in the lower panel show clear stimulus preference among LDs (first row) (ANOVA in the LD condition: $F=9.49, \mathrm{p}<0.001)$. The CTR stimuli did not elicit significant above background responses. 


\section{細}
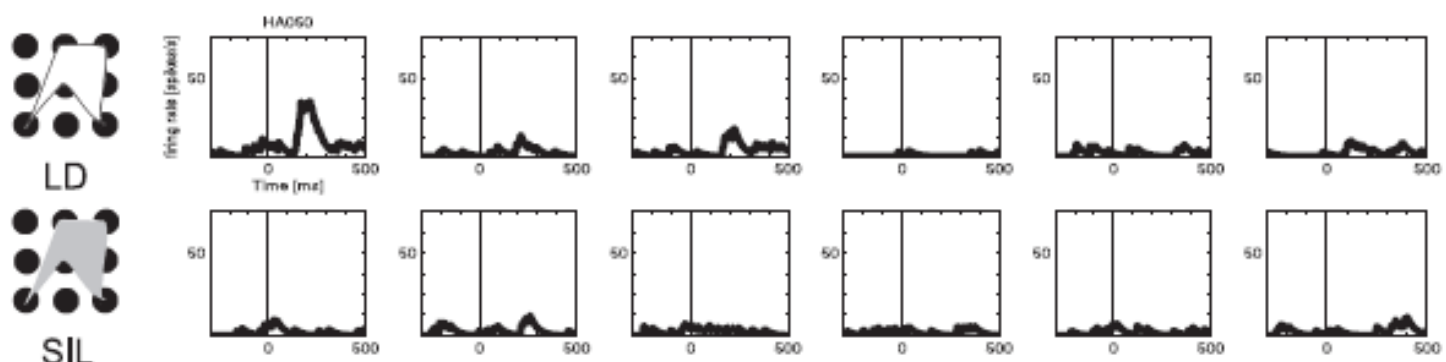

0
0
0

$\mathrm{KIC}$
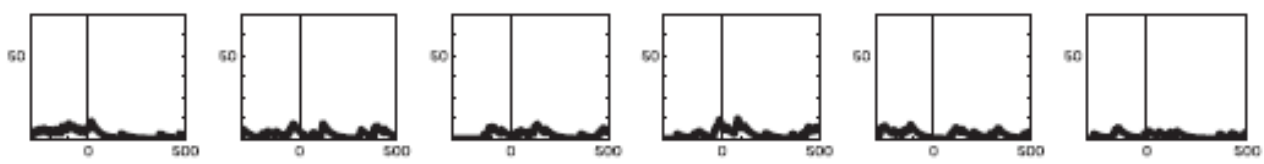

$\because$ ?

100

CTR
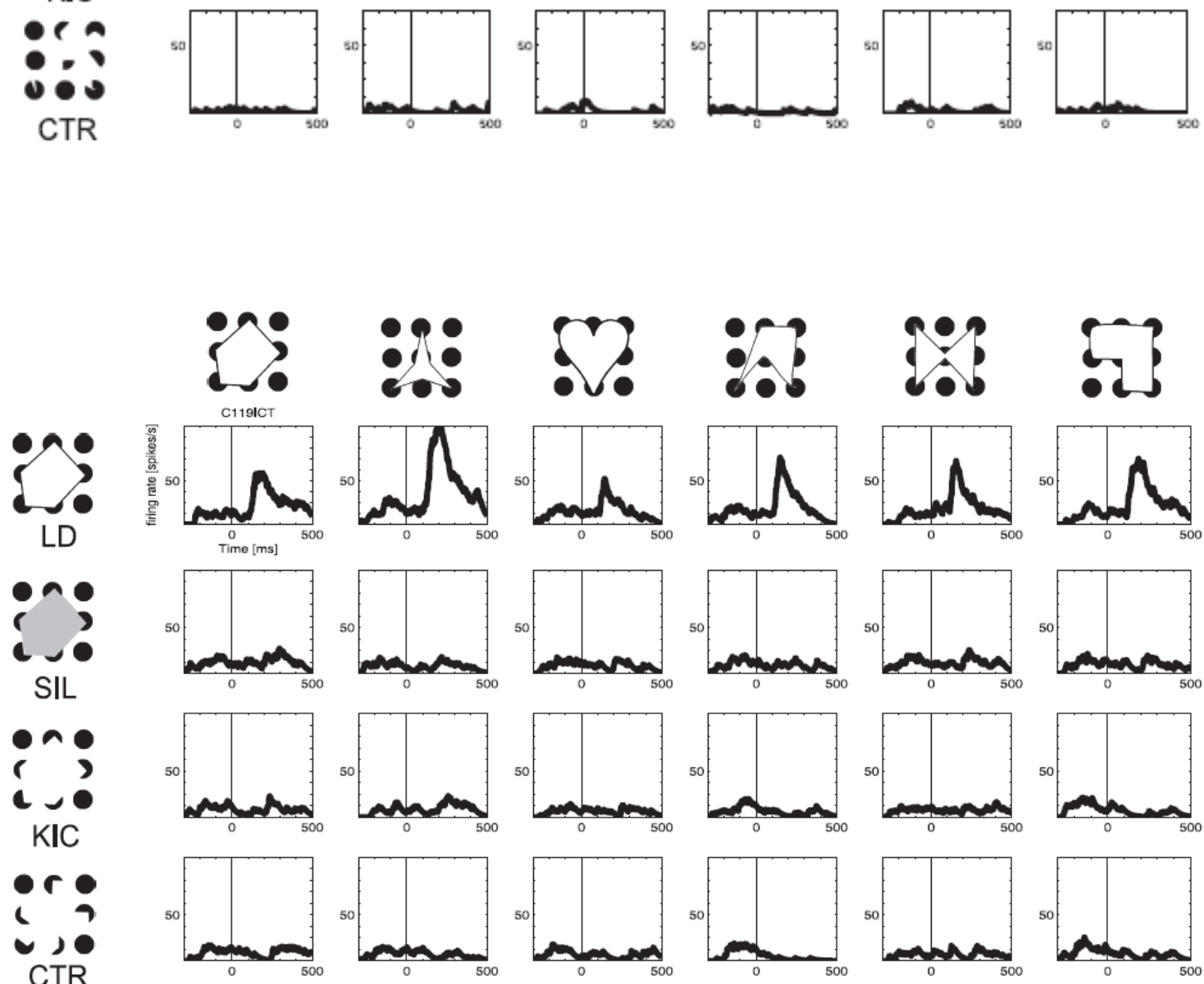

FIG 8: First cell shows stimulus selectivity, it responds only for one stimulus in the LD condition. The second cell also shows stimulus preference in the same condition. For explanation of the histograms see legend of Figure 2. 
To demonstrate that ITC cells react to KIC stimuli, Figure 9. shows a single cell responding to LD, SIL and KIC, but not to the CTR stimuli. The cell was shape selective: with the exception of CTR, responses within a condition differed markedly from each other as estimated with ANOVA (in the LD condition: $\mathrm{F}=31.54, \mathrm{p}<0.001$, in the SIL condition: $\mathrm{F}=$ 32.97, $\mathrm{p}<0.001$, in the KIC condition: $\mathrm{F}=20.34, \mathrm{p}<0.001$, in the CTR condition: $\mathrm{F}=4.71$, $\mathrm{p}$ $=0.1478$.
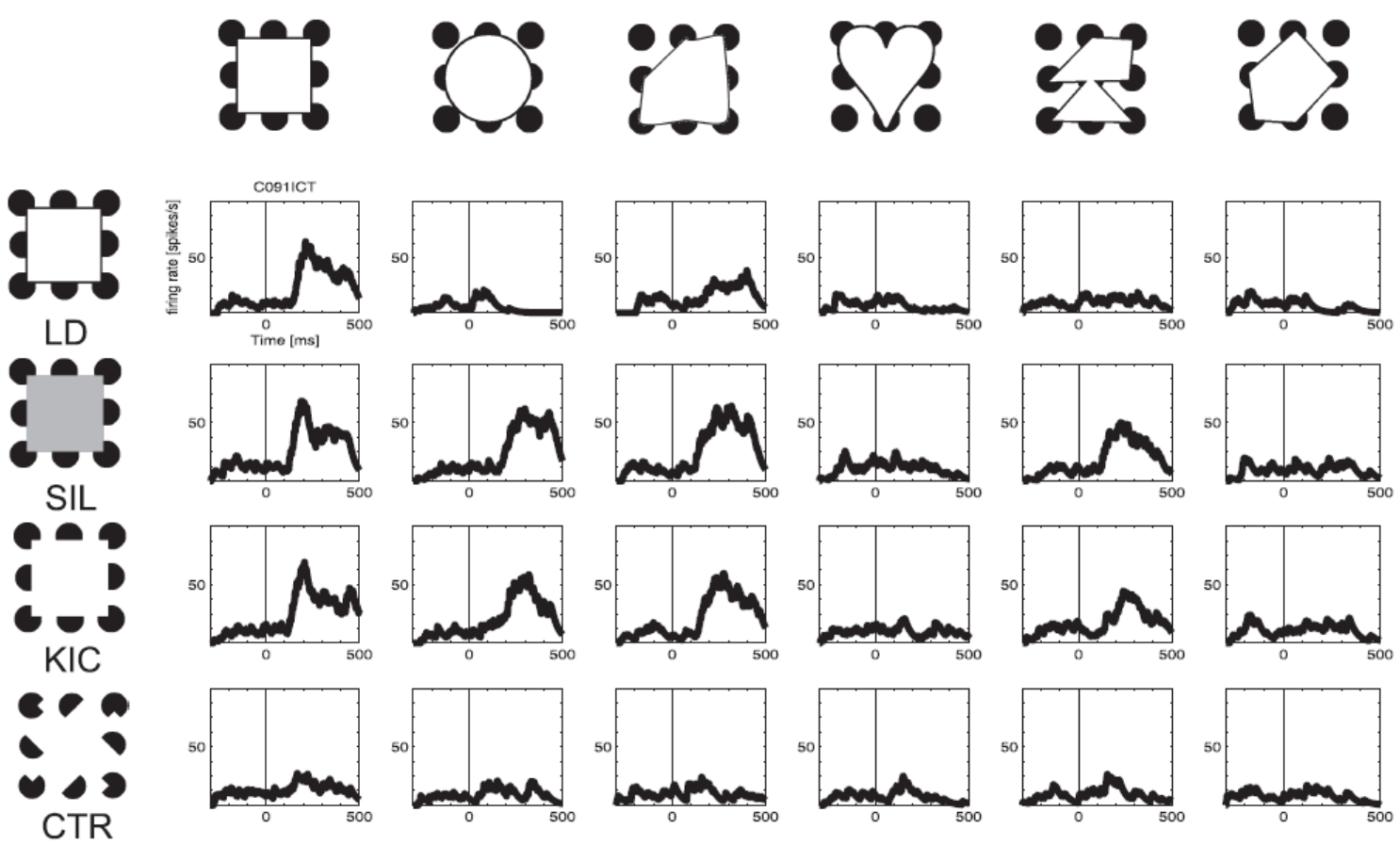

FIG 9: This cell above responds for KIC stimuli, but not for Control stimuli. For histograms see legend of Figure 2.

On the population level, the mean \pm SEM baseline activity was $11.7 \pm 1.11$ spikes $/ \mathrm{s}$ and mean responses given to the LD, SIL, KIC and CTR were as follows: $20.83 \pm 1.80,28.10 \pm 2.13$, $24.23 \pm 2.02$ and $13.31 \pm 1.7$ spikes/s, respectively.

Responses given to LD, SIL, KIC and CTR differed significantly (ANOVA, F=35.6, $\mathrm{p}<0.001$ ). A post-hoc (Fisher) test revealed that mean response levels to CTR were lower than in any other condition. This shows clearly that ITC cells react well in the different conditions, including KIC. The distribution of the responses in the different conditions can be seen (FIG. 10.). In addition, we found that responses to SIL were larger than to LD. 

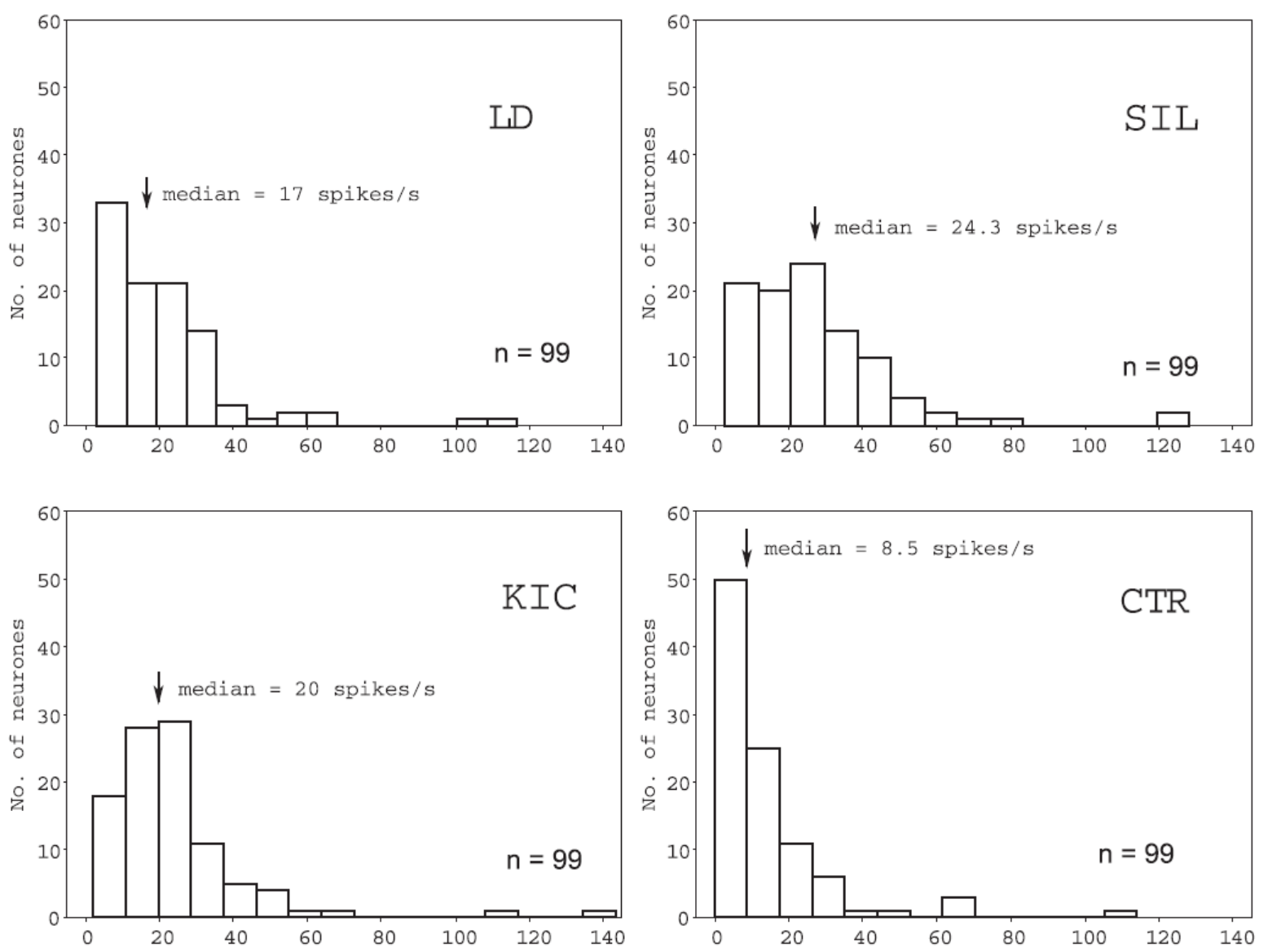

FIG 10: Distribution of the net responses of IT cortical cells in the LD, SIL, KIC and CTR conditions. The arrows indicate the medians of the distributions.

We also wanted to show whether ITC cells were capable of responding selectively to KIC stimuli. We found that $76.7 \%$ of the recorded neurons were selective for the presented KIC stimuli (ANOVA). Figure 11. (left) shows a population-tuning curve for these in the KIC and in the CTR condition. The tuning curves in the KIC and CTR conditions differed significantly. When the stimuli were ranked based on their responses to KIC (see methods), the tuning curve for KIC showed a significant slope (ANOVA, F=55.21, p<0.001) while the corresponding plot for CTR ran practically parallel to the $\mathrm{X}$-axis (ANOVA, $\mathrm{F}=1.05, \mathrm{p}<0.383$ ). This indicates shape selectivity for KIC.

To show how this shape selective-response of the ITC neurons relate to the responses evoked by the same stimuli having real contours, we performed the same analysis regarding selectivity described for KIC and CTR above for the responses to KIC, LD and SIL. Table 1. 
shows the number of cells having different or similar selectivity in the used condition and Figure 11. (right) presents the population tuning curves obtained in these conditions.
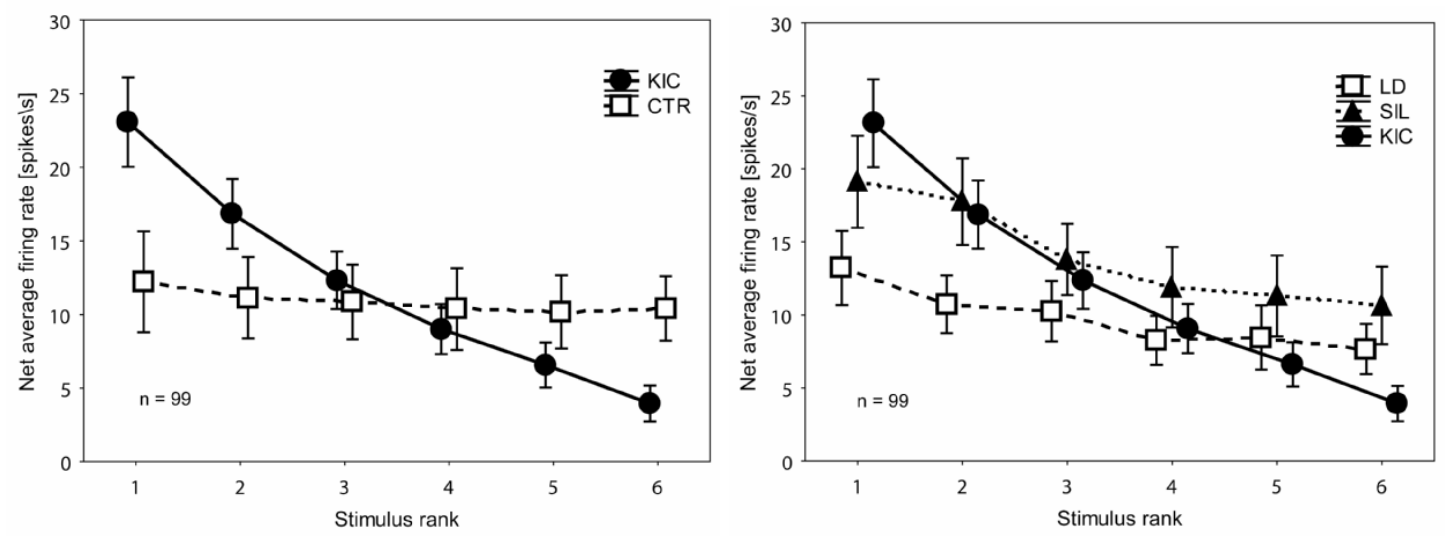

FIG 11: Population-tuning curves: KIC and CTR conditions (left), KIC LD and SIL conditions (right).

Table 1.: Cells with different or similar selectivity in the conditions

\begin{tabular}{|l|l|l|}
\hline Stimulus & $\begin{array}{l}\text { Different selectivity } \\
\mathrm{N}^{\mathrm{o}} \text { of neurones }\end{array}$ & $\begin{array}{l}\text { Similar selectivity } \\
\mathrm{N}^{\mathrm{o}} \text { of neurones }\end{array}$ \\
\hline LD vs. SIL & 79 & 20 \\
\hline LD vs. KIC & 86 & 13 \\
\hline LD vs. CTR & 87 & 12 \\
\hline SIL vs. KIC & 70 & 29 \\
\hline SIL vs. CTR & 83 & 16 \\
\hline KIC vs. CTR & 80 & 19 \\
\hline
\end{tabular}

The selectivity in the KIC, LD and SIL conditions differed significantly, showing the flattest slope for LD. As stated above, KIC evoked significantly larger responses from ITC cells than LD (Wilcoxon, $\mathrm{P}<0.001$ ). To exclude the possibility of having tuning curve differences based 
on markedly different firing fates, we repeated the same analysis, but with the responses ranked according to the responses to LD. The results were similar: as can be seen on Figure 12. (right), even though the tuning curves show a similar course, there was a highly significant difference between the tuning curves obtained for LD and KIC $(F=17.14, p$ $<0.001)$.

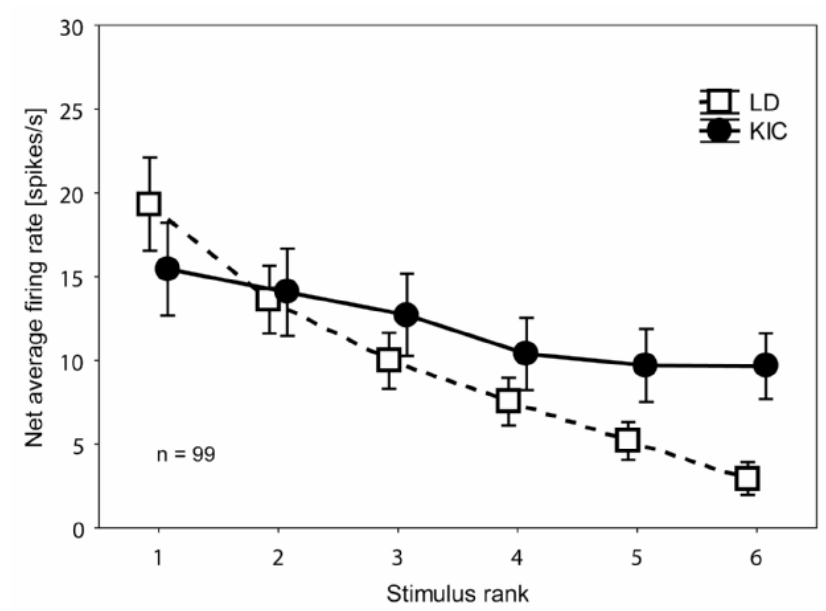

FIG 12: Population-tuning curves: LD and KIC conditions

Since Kanizsa images often make the impression of a floating plane above the inducing elements, and ITC cells are sensitive to the inner features of a particular stimulus (Vogels \& Biederman 2002) we tested whether the activity level evoked by KIC were similar to those to SIL of the same shapes.

The responses evoked by SIL were greater than those evoked by KIC (Wilcoxon, $\mathrm{P}<0.001$ ), but we found a highly significant correlation between responses given to SIL and KIC (Spearman Rank Order Correlations, 0.77, p<0.05). Still, although the slope of the tuning curves obtained for KIC and SIL are more similar to each other than for KIC and LD (FIG. 11. right), there was a significant difference between the curves (ANOVA, F=20.61, $\mathrm{P}<$ 0.001). It is worthwhile noting that the largest ratio of cells having similar selectivity was found in the KIC-SIL comparison (Table 1).

\section{Response latencies}

There are several ways of measuring response latencies and the values obtained depend partly on the used method. The latency values obtained by the Poisson spike train analysis in the 
different conditions were $136.47 \mathrm{~ms} \pm$ SD 34.96 for LD, $135.39 \mathrm{~ms} \pm$ SD 30.33 for SIL and $147.99 \mathrm{~ms} \pm \mathrm{SD} 36.06$ for KIC. We found significant differences as estimated by ANOVA $(\mathrm{F}=7.30, \mathrm{P}<0.001, \mathrm{n}=76)$, the latency values for KIC were longer than those measured in the two other conditions (FIG. 13.).

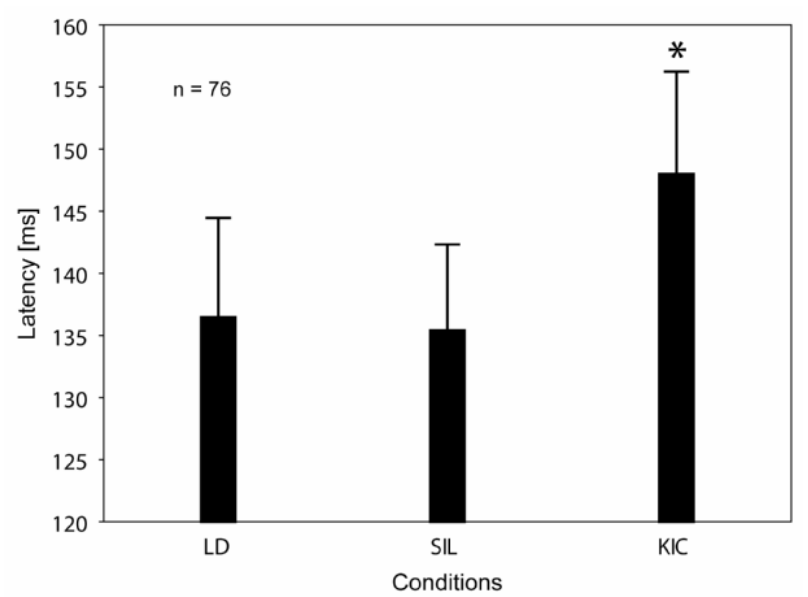

FIG 13: Mean neuronal response onset latency values for LDs, SILs and KICs. Bars indicate means, whiskers show 0.95 confidence intervals. 


\section{Discussion I}

To the best of our knowledge, this is the first single-cell recording study using KIC stimuli in the IT cortex of primates.

We presented shapes having real contours (LDs, SILs) and KICs to fixating monkeys while recording the neuronal activity in the ITC, and compared the responses to KICs and real contours. Our main findings can be summarized as follows:

a) The neurones in the ITC are responsive to KICs.

b) The neuronal response onset latencies for KICs are longer than those for shapes with real contours (LDs and SILs).

c) The IT cortical cells exhibit clear shape selectivity for KIC stimuli.

d) The shape selectivity of the ITC neurones differs from that for LDs or SILs, but the degree and similarity of selectivity were the closest between KICs and SILs.

a) The present study complements the recently published one by (Sary et al. 2007), where ICs based on abutting-line gratings were used as visual stimuli. We found that in contrast to the previous study, where the abutting-line stimuli elicited much smaller responses than did the stimuli with real contours, KICs proved to be very effective stimuli with the mean response level to KICs somewhat even higher than that for real contours.

KIC stimuli elicited much higher responses than the CTR stimuli, which suggests that the responses to the KICs are due not only to the inducers (the pacmen), but also to the KICs inducing the shape from the background, even if real contours are absent.

This is in line with the results where variants of the pacmen did not change P1 waves in a visual evoked potential study using Kanizsa type stimuli (Brodeur et al. 2006), although the P1 wave is known to be very sensitive to the physical features of the stimuli (Jeffreys 1996).

b) The response latencies to the KICs were longer than those to the stimuli with real contours, LDs or SILs. Our latency values fit nicely with the latency values obtained for ICs, which range from $130 \mathrm{~ms}$ to $180 \mathrm{~ms}$ (Bottger et al. 2002; Kruggel et al. 2001), associated with the lateral occipital cortex (Murray et al. 2004). 
Moreover, the use of KIC stimuli revealed that the most prominent evoked responses occur only at $\sim 150 \mathrm{~ms}$ over the anterolateral occipital cortex (Halgren et al. 2003) which is considered to have a similar function in humans like the ITC in monkeys (Grill-Spector et al. 2001; Kourtzi \& Kanwisher 2000; Grill-Spector et al. 1998).

Processing of ICs is delayed in the early parts of the visual pathway as well. V1 neurones are responsive to the orientation of ICs defined by abutting gratings and KICs (Ramsden et al. 2001; Lee \& Nguyen 2001), but the responses emerge later than those for real contours. This delay and the fact that the responses in V1 emerge $30 \mathrm{~ms}$ later than those in V2 suggest possible intercortical interactions during the processing of ICs. (Some findings suggest that when abutting-line gratings are used as stimuli, the orientation maps in V1 and V2 depend critically on the spatial frequency of the stimuli (Zhan \& Baker, Jr. 2008), and IC sizes in the interval $5-10^{\circ}$ do not elicit significant responses over V1/V2 (Murray et al. 2002; Mendola et al. 1999).

c) Our data indicate that neuronal responses from the ITC to KICs can be used to construct tuning curves with a significant slope, while the same curves for CTR stimuli are essentially flat.

This shows that ITC neurones have a stimulus preference and can reliably discriminate between stimuli even in the absence of real contours. Human studies suggested the contribution of the anterolateral occipital cortex in illusory shape perception (Halgren et al. 2003; Pegna et al. 2002; Kourtzi \& Kanwisher 2001; Kruggel et al. 2001). Here we provide direct evidence that the monkey ITC can code unambiguously the presence of illusory contours in the stimuli. In this respect, these findings mirror the results of the previous study (Sary et al. 2007) and suggest that ITC cells with shape selective responses to KICs (and to ICs in general) might participate in the perception of IC-defined shapes where no real contour information is available.

d) In our previous study we found that the selectivity of ITC cells was different for coloured stimuli and ICs, but IC selectivity did not differ from that of SILs (Sary et al. 2007). The present study demonstrated that shape selectivity for KICs was different from those for the 
SILs and LDs. This is somewhat surprising, since KICs usually give the impression of a floating surface, which lack internal visual surface information, in a similar way how SILs do. There are different possible explanations for this. On one hand, ICs contain much more ambiguity than real contours or SILs and thus are harder to perceive, which is also reflected in longer reaction times in psychophysical studies (Brodeur et al. 2008; Rajimehr et al. 2003; Ringach \& Shapley 1996) and longer neuronal onset latencies in ITC (Sary et al. 2007). On the other hand, ITC cells might react to forms defined by different visual cues similarly, but they are not invariant to depth segmentation, which is a common phenomenon associated with KICs. ITC responses depend not only on the presented shape, but also on the border ownership polarity of the contours (Baylis \& Driver 2001). The presence of the additional depth information in the KICs and the absence of the same in SILs might explain the differences in the tuning curves we observed.

Shape selectivity of ITC neurones is a well-studied issue (Sary et al. 2007; Tompa et al. 2005; Kovacs et al. 2003; Vogels \& Biederman 2002; Sary et al. 1993). This selectivity may underlie the perceptual invariances of object recognition (Tompa et al. 2005; Kovacs et al. 2003; Vogels \& Biederman 2002; Tanaka et al. 2001; Rolls 2000; Sary et al. 1993)

We think that the relation of shape preferences of ITC neurones for the KICs and the real contour defined shapes might form the basis for the perceptual effects observed for real and illusory contours (Brodeur et al. 2008; Dresp \& Bonnet 1995; Berkley et al. 1994; Paradiso et al. 1989; Vogels \& Orban 1987; Smith \& Over 1979).

Our results confirm the role of ITC in visual shape perception and generalize the ITC function in object and shape coding into the IC domain.

Two possible mechanisms of processing contours or surfaces physically not present (especially in those areas where the receptive fields of the neurons are smaller than the distance between the inducers) are the lateral connections and the feedback flow of information.

In the first case cells, which have line endings or inducers interpretable as line endings in their receptive fields can facilitate other cells having similar orientation selectivity and receptive fields situated between the facilitators, inducing thereby the percept of a dim line (Li et al. 2006; Bauer \& Heinze 2002; Kasamatsu et al. 2001; Kapadia et al. 1999; Polat et al. 1998; Rockland et al. 1982). 
In the second case, cells in higher order visual areas having large enough receptive fields to contain two or more inducers can facilitate backwards those cells, which would participate in the representation of the shape (surface or contours) formed by the inducers (Givre et al. 1994; Bullier \& Henry 1979). Of course the two strategies are not excluding each other, they can even work together in shaping the appropriate percept (Oliva \& Schyns 1997).

These strategies are paralleled by the scene-segmentation strategies of edge detection versus surface representation. An effective conducive to the recognition of objects - especially if they are occluded - is the exploration of their borders, i.e. a kind of edge-detection. Indeed, it seems that an important feature of visual neurones is the representation of oriented lines.

At the same time, it is at least equally important to have information about whose border the given line is, namely the border ownership. The borders are borders of surfaces, so one has to identify the surfaces to assign them.

Which strategy dominates in the recognition of illusory contours and generally of objects? Is one of them dominating at all or do they act together in the process of recognition?

An empirical way to find the strategy can be the analysis of the response latencies and the comparison of the responses of individual neurons given to the illusory contours and to the illusory versus the real contours - in a given area or at different levels of the presumed hierarchy of the visual system. The response latency of the neurons recorded by us is longer in the case of the illusory contours (see also (Sary et al. 2007)) than of the real ones and of the silhouettes that represent the surfaces. This means additional processing, i.e. those higher order visual areas do not rely simply on the feed forward information flow when identifying shapes.

More cells had similar selectivity for the KIC and SIL conditions than in the case of the KIC vs. LD comparison (see Table 1.) indicating that the processing of illusory contour-defined shapes shares more features with surface processing than with contour or edge processing. A similar conclusion can be drawn from the case of the abutting grating-defined ICs (Sary et al. 2007), where even the selectivity for the IC and SIL conditions were similar. However, we found cells having similar contour selectivity for illusory and real contours, which means that the strategy of edge detection is also present in the system. (There were also cells with differing selectivity for all three conditions. They may contribute to a third strategy.) 
Given that there is a level of invariance for the shapes defined by different cues at the behavioural level, we must conclude that the different neural strategies will indeed yield the same or similar behavioural outcome.

The longer response latency in early visual areas for ICs as compared to real contours (Lee \& Nguyen 2001) suggests a role for feedback connections in processing of subjective contours. A good candidate for the origin of this feedback information would be the global shape processor ITC.

Indeed, so far a number of studies have shown that these higher order visual areas (both in humans and monkeys) have a substantial role in the IC processing (Montaser-Kouhsari et al. 2007; Seghier \& Vuilleumier 2006; Imber et al. 2005).

However, neuronal response latencies in the ITC are still longer than those for the real contours, and this finding is consistent with our previous results (Sary et al. 2007). This fact suggests that ITC is not the sole provider of this information but seems to require further cortical sources to provide the information for the visual system. Then where does this information emerge from?

In the case of illusory contours it is strengthened by the required grouping effect of the inducers (Elder \& Zucker 1998) and by the illusion that the surface of the illusory object is perceived brighter than the surrounding. Based on the above presented evidence, one can conclude that the higher order areas play a role in the processing of the shapes defined by illusory contours. They can be the source of feedback information going to early visual areas, which, in turn are needed for the detailed representation of the figures (Pillow \& Rubin 2002; Lee 2002) but, at the same time, they seem to need more computation than for the processing of shapes defined in a more unambiguous way. 


\section{Experiment II: Auditory modulation of the inferior temporal cortex neurons in rhesus monkey}

\section{Introduction}

There is a growing number of the evidence to support the idea that there are no separated unimodal systems, which exchange information only in the association areas to process them (Budinger et al. 2006; Schiller 1996). There are connections between these areas, they are communicating, and they have an effect on each other. Even the primary visual area might respond to modalities other than light: visceral signals have been shown to activate neurons in area V1 of cats and monkeys (Pigarev et al. 2006; Pigarev 1994). In PET experiments, tactile and auditory stimuli activated visually sensitive cortices in congenitally blind subjects (Burton et al. 2002; Weeks et al. 2000), whereas the auditory cortex was found to be activated by visual stimuli in deaf people (Finney et al. 2001). In a PET investigation, some of the ventral visual areas could be activated by sounds (Buchel et al. 1998), and fMRI studies have revealed multisensory interactions in the primary visual and auditory cortices (Martuzzi et al. 2007).

It is also known from everyday experience and from psychophysical studies how intricately visual and auditory information act together in shaping our knowledge of our surroundings and our acting in them.

Thus, we found it advisable to study the effects of auditory stimulation in that area, regarded as unimodal, in the anterior part of the inferotemporal cortex (TE). Inferotemporal cortex ITC is considered to be the last unimodal visual stage in the ventral visual stream (Tanaka 1996; Ungerleider \& Mishkin 1982), consisting of several subregions, like anterior, middle and posterior part (Tamura \& Tanaka 2001). This is not the first study to test the effect of auditory stimuli in ITC, but they used the sound as a warning signal or joined it with act. In one of these studies (Iwai et al. 1987), one third of the recorded neuronal population in the ITC responded to pure tones. Another one (Watanabe \& Iwai 1991) reported neurons of the posterior part of inferotemporal region (TEO) reacting to auditory signals, while others obtained similar results in ITC in split-brain monkeys (Ringo \& O'Neill 1993). However, these studies might have found attention or action dependent modulated responses. Baylis et al. reported neurons receiving auditory signals mostly in TS and TAa areas of the temporal 
cortex (Baylis et al. 1987). They did not find considerable auditory activity in IT with poorly described auditory stimulus exactly. In this study, we tested whether the neurons of the TE area of inferotemporal cortex, responsive to visual stimulation, could react to sole auditory stimulation. 


\section{Material and Methods}

Stimuli

Colourful, complex images were shown on a standard computer display (FIG. 14.). Visual stimuli had a viewing angle of $5 \times 6 \mathrm{deg}^{2}$, and mean luminance was set at $\sim 8 \mathrm{~cd} / \mathrm{m}^{2}$. Auditory stimuli were presented from a computer loudspeaker positioned on top of the stimulation display (app. $60 \mathrm{~dB}, 440,466,493,523,554,587,622,659,698,739,783,830,880,932$, 987, 1046, 1108, 1174, 1244 and $1318 \mathrm{~Hz}$, respectively).

Three stimulation conditions were used: one unimodal condition contained only the visual images (VIS); the other unimodal condition had only the auditory stimuli (AUDIO). For bimodal stimulation (condition: AUDIOVIS) the visual images were paired with those of the auditory stimuli. These pairings were fixed, i.e., an image was always presented with the same sound. A screen with a grey background, without the sound served as control.
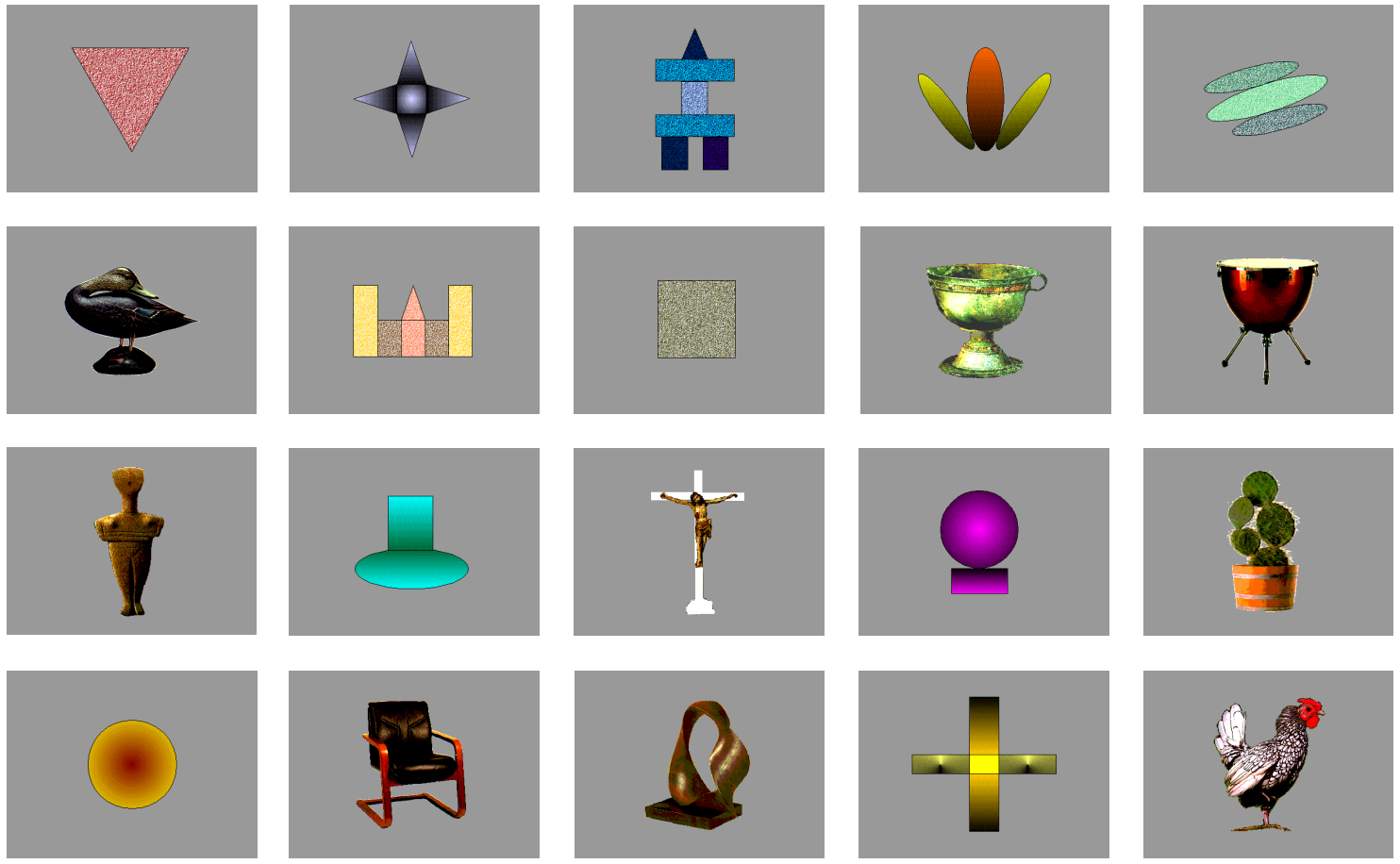

FIG 14: Set of colourful, complex stimuli 
Stimulus sequence

A simple fixation task was used in this experiment. Trials started with the onset of a fixation spot, which was followed by a grey background (500 ms). Visual stimuli (VIS) appeared in this background and were presented for $500 \mathrm{~ms}$. In the AUDIO condition, the grey background stayed on for another $500 \mathrm{~ms}$, but a sound was presented instead of the images. In AUDIOVIS condition, sound was presented with the images for $500 \mathrm{~ms}$. The animals were rewarded for fixating on the fixation spot within $\sim 200 \mathrm{~ms}$ after the disappearance of the stimuli (FIG. 15.). Neurons were isolated with the use of the VIS condition. Then, some stimuli (10 for monkey $\mathrm{Ch}$ and 6 for monkey Z) evoking stronger or weaker responses were selected. Next, during the registration, visual stimuli (VIS), sounds alone (AUDIO) and combined audiovisual stimuli (AUDIOVIS) were presented in a semi-random order, at least ten times each.

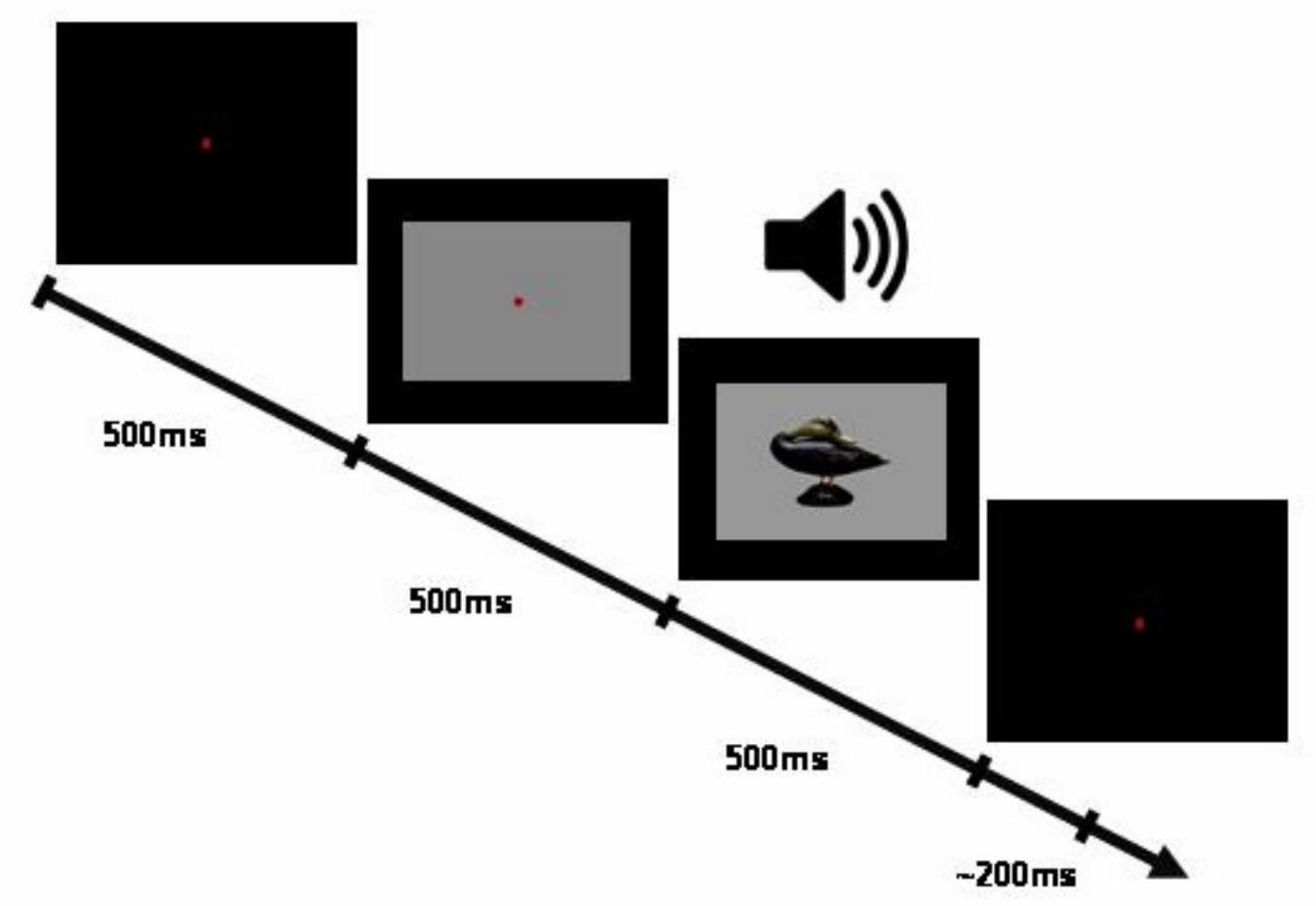

FIG 15: Stimulus presentation starts with a fixation point (FP). When the monkey is fixating a grey background appear behind the FP $(500 \mathrm{~ms})$. It is used for baseline calculation. Then the stimulus is presented for $500 \mathrm{~ms}$. If the monkey is watching the monitor during the trial, it is rewarded. 
Data analysis

For the calculation of net firing rates, the baseline activity (given to the grey background, measured in a $400 \mathrm{~ms}$ time window before stimulus onset) was trial wise subtracted from the responses (measured between $100 \mathrm{~ms}$ and $500 \mathrm{~ms}$ after stimulus onset).

T-test was used to test responsiveness of the cells when comparing the background and the firing activity during the stimulus presentation.

Friedmann ANOVA non-parametric test with a post-hoc Sign-test for dependent pairs was used to test the selectivity. Tests were classified significant if the corresponding type I error was $<0.01$.

Since inferotemporal neurons might exhibit stimulus-preference, a selectivity index (SI) was calculated, based on the following formula:

$\mathrm{SI}=\mathrm{R}_{\max }-\mathrm{R}_{\min } / \mathrm{R}_{\max }+\mathrm{R}_{\min }$

where $R_{\max }$ is the maximal and $R_{\min }$ is the minimal response to a stimulus from the stimulus set, respectively. The closer this index is to " 1 ", the bigger the difference between a "preferred" and a "non-preferred" stimulus is, i.e., the more selective the neuron is.

For finding a modulatory effect in the AUDIOVIS condition, we made the following analysis: we selected a neuron responding to at least one member of the stimulus pairs in the VIS and in the AUDIOVIS conditions. Net responses were compared with a t-test. A cell was regarded as "modulated" if there was a significant difference in the responses given to the stimulus pairs.

Latency measurements were performed using a modified Poisson spike train analysis in each case in which a stimulus triggered a response. 


\section{Results II.}

General responsiveness

From the isolated units 92 neurons were responsive at least in one of the three conditions (monkey 1: 67, monkey 2: 25). Since there was no difference between the results of the two animals (regarding response amplitude, response latency, SI indices), data were pooled. In general, neurons responded well in the VIS and also in the AUDIOVIS condition (mean net responses $23.5 \pm 18.5$ and $22.8 \pm 19.3$ spikes/s, respectively), showing the well-known stimulus preference of ITC units (mean SI: $0.573 \pm 0.227$ and $0.573 \pm 0.226$ in the VIS and AUDIOVIS conditions). There was no significant difference between the mean neuronal response latency in the VIS condition $(137.8 \mathrm{~ms} \pm 35.8)$ and the AUDIOVIS condition (136.9 $\mathrm{ms} \pm 36.3)$.

Response/modulation in ITC by auditory signals

There were 9 cells (10\% of the sample), which responded at least to one of the auditory signals in the AUDIO condition, having a mean firing rate of 7.15 spikes/s \pm 4.05 (FIG. 16.). There was no difference in the firing rate between the different conditions in this sub-sample. The mean latency time to the AUDIO was $137.70 \pm 32.3$ which did not differ significantly from the latency times measured in the VIS $(129.43 \pm 25.4)$ or AUDIOVIS $(128.13 \pm 26.3)$ condition in the same cells as tested with Friedman ANOVA.
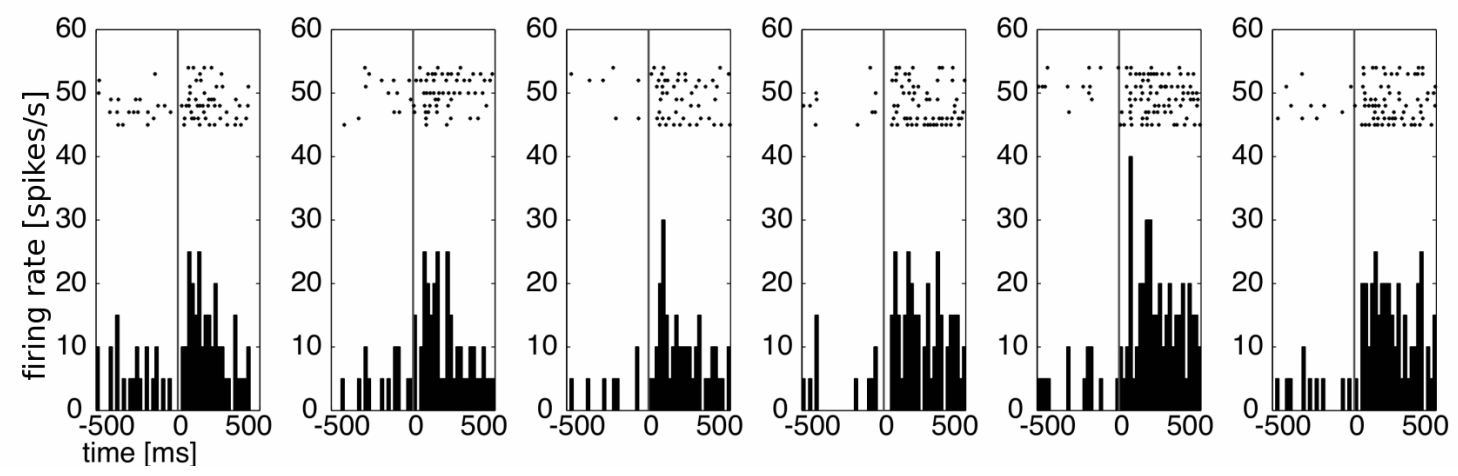

FIG 16: Responses of a single cell in TE for sounds.

In 22 neurons ( $24 \%$ of the sample), although responses given in the AUDIO condition did not reach significance level (except 5 neurons), the responses differed between the VIS and the AUDIOVIS conditions at least in one of the stimulus pairs (16 cells 1 pair, 5 cells 2 pairs, 
1 cell 3 pairs). Figure 17. shows examples, where responses given to a VIS stimulus were modulated in the bimodal, AUDIOVIS condition.
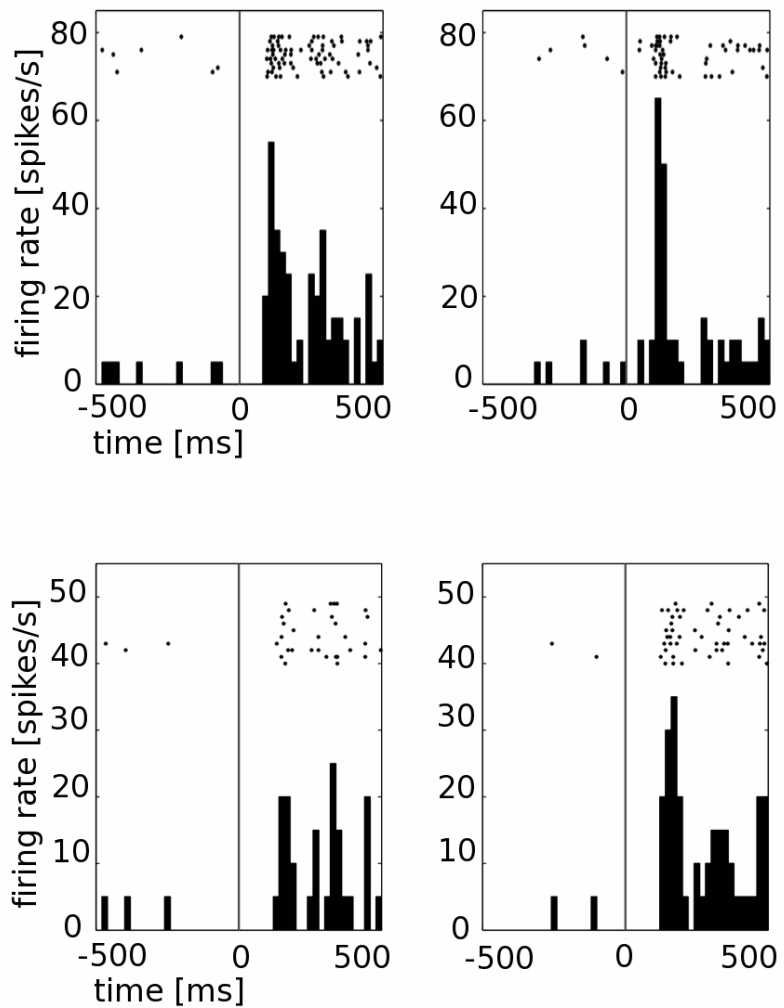

FIG 17: Examples of two ITC neurons response modulation. The left sides in both panels show the neuronal responses to the visual stimuli, while the right sides show their responses when the visual and auditory stimuli were presented simultaneously.

We could not find a universal pattern for the modulation, i.e., response rates could either increase or decrease in the bimodal condition as compared to responses in VIS. The distribution of response changes between the conditions is shown in Figure 18.

Response latency values on the population did not differ significantly between VIS and AUDIOVIS. Some cells showed an increase, others a decrease in the latency when changing stimulation condition. The distribution of latency differences is presented in Figure 18. 

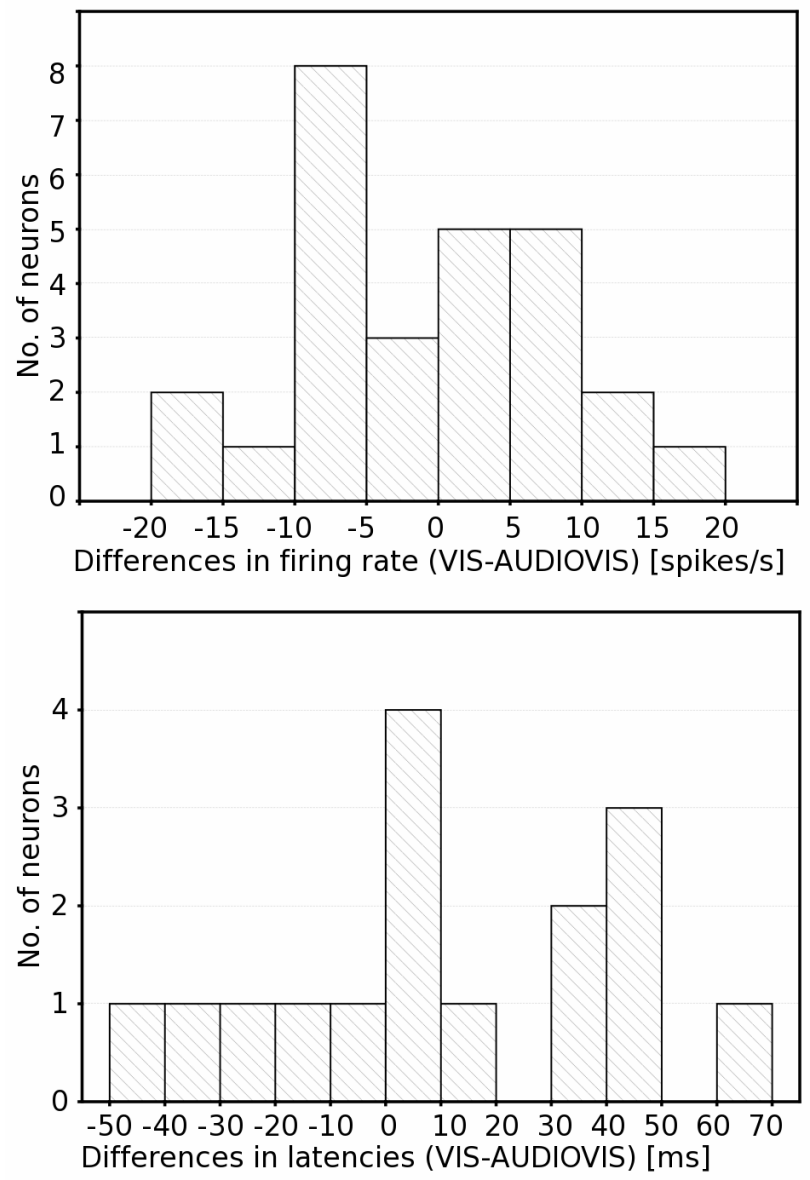

FIG 18: Effects of audio-related modulation in the ITC. The upper panel shows the distribution of the differences in firing rates between the VIS and AUDIOVIS conditions. The lower panel shows the distribution of the latency differences between VIS and AUDIOVIS. 


\section{Discussion II.}

We found a number of neurons in area TE of the ITC responded to auditory stimulation and also showed the modulation of responses induced by visual stimuli when they were presented simultaneously to auditory stimulus. This is clear evidence that auditory modality does have an effect on the ITC neuronal visual responses and that it impacts information processing at a stage previously regarded as unimodal.

A connectivity study of Saleem et al. (2000) reported anatomical connections between area TE and the SPS, thus, there might be a "pre-wired" pathway for sound stimuli that reaches the inferotemporal cortex.

Earlier reports exist on sound related activity in the inferotemporal cortex of the monkey. In the next section, we compare these studies with our present study. In general, with the exception of Baylis et al. (1987), who did not present sufficient data concerning the auditory stimulus parameters and stimulating conditions, none of the papers discussed below presents pure auditory effects in area TE. Other research group (Desimone \& Gross 1979) failed to find cells in this area. However, we must note that they used anaesthetized animals. This might explain the differences between their and our studies, even if our animals had to perform only a simple fixation task.

In a study (Iwai et al. 1987), the precise recording location, i.e., TEO or TE was not defined, and the sound was presented earlier than the visual stimuli. The response latencies for the auditory signal were long (on average over $500 \mathrm{~ms}$ ), excluding a direct auditory effect on ITC cells, because of the much shorter latency values observed in these neurons. As the authors also stated, the sound related signals were more probably a manifestation of some attentional mechanisms.

Watanabe \& Iwai (1991) performed their recordings in areas like the auditory area (AA), STP and TEO of the ITC. On one hand, the closest area to TE, the TEO did not respond to the isolated auditory signals. AA and STP contained several sound responsive neurons, which is not surprising, since these areas are known to be auditory and polysensory (Watanabe \& Iwai 1991). Cells in area TEO did not react to the sounds only, but also caused a modulation of the visual responses. Again, this modulation seems to be attention-dependent, since the monkey was warned by the sound. Similarly, in the study of Ringo \& O'Neill (1993), split brain monkeys were exposed to alerting tone signals, while recording in ITC. Some neurons were 
responsive (17 cells from 308 units) to the warning signals, but warning preceded the visual stimuli. The authors also stated their results resembled those of Iwai et al. (1987).

In our study the sounds did not carry biological relevance. The animals were fixating, receiving their reward for keeping their eye on the fixation spot. For this reason, what happened on the screen, or what sound was presented during the visual stimulation, was irrelevant for the monkeys. Finally, we believe that the results we present are due to the sensory processing of the auditory stimuli and not to some task related or attentional effect.

In this study, we wanted to clarify whether or not ITC neurons in TE area responded to auditory signals presented together with visual stimuli. We report that a substantial number of ITC neurons in the monkey responded to auditory stimuli, or modulated their responses to visual images when visual and auditory stimuli were presented simultaneously. We believe that our results represent the first real report on auditory sensitive neurons in the monkey inferotemporal cortex, in area TE. This implicates that correlated sensory modalities might converge and have modulatory effects in sensory areas earlier considered as strictly unimodal, even if the stimuli belong to different modalities. 


\section{General discussion}

The ITC is absolute necessary for object and shape vision. The responses show different patterns, but retinotopy is very loose if any in the ITC. This fact and the large receptive field which include the fovea with the position invariance of the cell's responses suggest an abstract way of the coding.
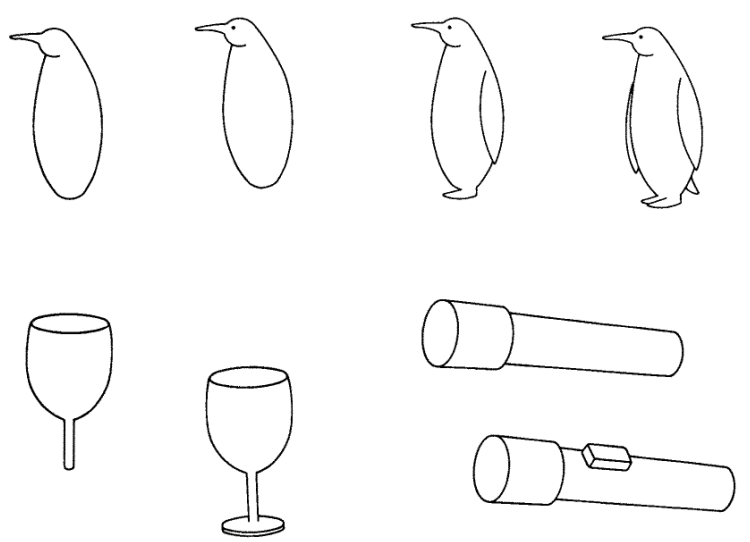

FIG 19: The information about objects of the environment can be represented by components (Biederman 1987)

Early studies suggest a theory, where coding of objects is based on the representation of so called geons (Biederman 1987). They suggest a way of perception which is basically coding different 3D profiles. This set of geons (geometrical icons) could overlap with the objects or object parts of the environment (FIG 19). If this type of coding exists in the visual system, it is possible to find traces of this coding in ITC. We didn't find this feature of ITC in preliminary experiment, although other authors did (Vogels et al. 2001).

Electrode penetrations perpendicular to the surface of the cortex identified cells with similar stimulus preferences (Wang et al. 1998; Fujita et al. 1992). It supports the conception of another laboratory (Tanaka 1996). They suggest a columnar organisation of the ITC, where each column has a size of about $0.5 \mathrm{~mm}^{2}$ and contains cells responding to different physical parameters of the stimuli (FIG. 20.). These columns might overlap with each other. The cells 
in one column have similar but not identical responsivity for a visual image, and for another image they could be in different columns (FIG. 20, 21). Thus, the activity pattern of the cells within one column and the combination of the columns can represent the diverse visual environment. The estimated number of cortical columns is 1300 (Tanaka et al. 2003).
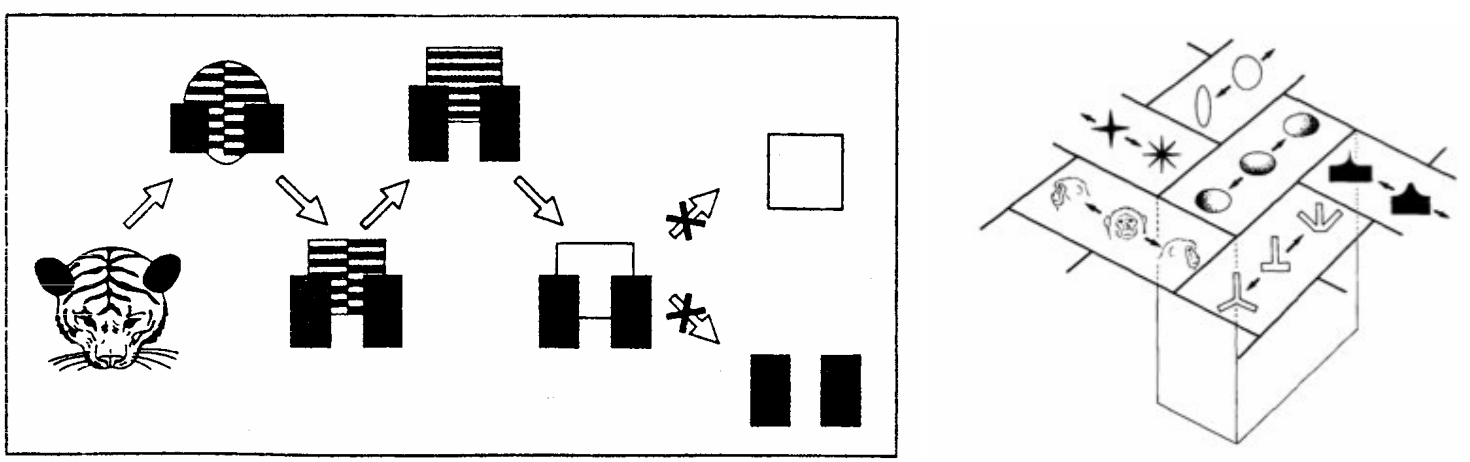

FIG 20: The neurons, tested by stimulus reduction, show columnar organisation in ITC. Left panel shows how cellular responsivity was kept and at the end lost when the tiger head was reduced step by step. The columns, positioned side by side, have different stimulus preference (Tanaka 1996; Tanaka et al. 1995).

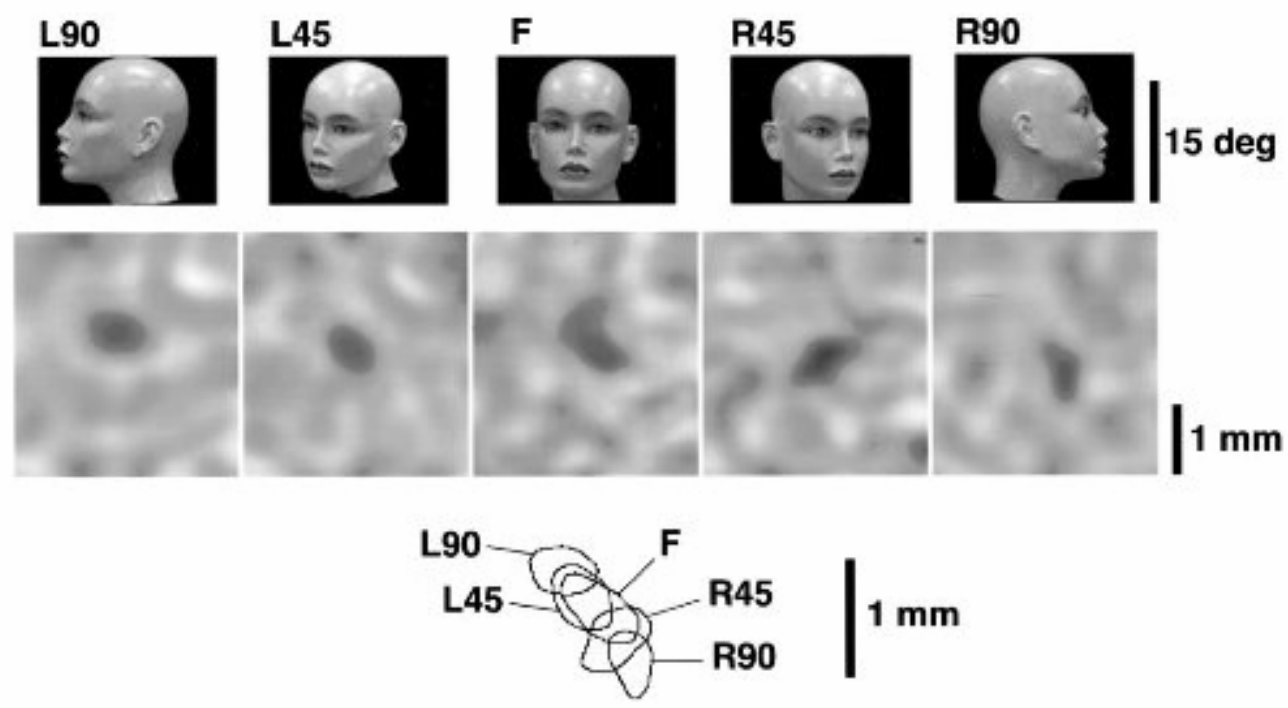

FIG 21: The cortical columns activated by different views of the same head partially overlap with each other, thus this area is able to make more complex computations (Tanaka 2003). 
Optical imaging and extracellular recordings also revealed a columnar organization in the ITC (Tanigawa et al. 2005; Tsunoda et al. 2001). These studies suggest a modular functional architecture, meaning that the representation of individual objects is not monolithic but rather is based on a combination of modules. Kreiman et al. (2006) made the interesting observation that the LFPs in the ITC were often image-selective and that this selectivity was poorly reflected in the spiking activity recorded at the same site; the LFP stimulus selectivity could be better explained by combining the cellular spiking responses in the given area in the ITC.

Another approach suggests a different solution for coding visual stimuli. In this theory, the visual coding of the ITC is based on the categories (Logothetis \& Sheinberg 1996). Their principle examples are the sensitivity for the faces and the body parts (e.g. hand shapes). This is a strong reason to perceive the ITC as an analogue to the human fusiform gyrus. In clinical observation they found that the damage of this area causes a failure in ability of face recognition (prosopagnosia). The representation of the categories in ITC by the single cell activity is not clear. There are several inconsistent papers. Sugase et al. (1999) found that the initial part of the neural responses included information about the stimulus category (human face, monkey face and form), the later parts of the responses carried information about face identity or expression. The early part of the response might also code such hard-to define categories as the simplicity or complexity of the images presented to awaken monkeys (Sary et al. 2004). The use of a large stimulus set indicated that the later part of the responses in the ITC (240 ms after stimulus onset) was more selective for the stimulus than the early one (Tamura \& Tanaka 2001). But recent findings from Akrami et al. (2009) show that the first part of the responses of ITC neurons produces a linear representation of the stimulus, while the latter one represents one of the classified categories.

In addition, in a recent paper the baseline (resting) activity, as a part of the prior, shows the pattern of the previous visual inputs (Fiser et al. 2010). This kind of Bayesian learning could be fundamental in information perception and processing.

The briefly mentioned theories are fundamentally different but they may not be conflicts among these theories; they can work in parallel. None of them explains the complete rules of coding in the IT or in the visual system. The theory of Tanaka might give the foundation. It does not exclude the geon theory, which seems to be obligate to represent $3 \mathrm{D}$ objects or object 
parts. On the other hand, geons can be considered as a category. Thus, this conception can be included in the coding based on categories theory. Between the coding based physical parameters and the coding based categories the bridge could be the "learning" of the system.

The experiments presented here fit in the history of the laboratory. Shape processing of the TE was investigated in a systematic way. Shapes with reduced surface information were tested (Kovacs et al. 2003). Colour, texture, shading, contrast and inner contours were systematically removed from the stimuli. Shape selectivity of the cells was not changed, but the responses were bigger for the coloured shapes in comparison to the reduced version of them. The same result was found with achromatic stimuli. The shape selectivity was not changed, but the response rate decreased in the black and white condition (Tompa et al. 2005). In a preliminary experiment we found possible selectivity difference between colour shapes and line drawing (Kaposvári et al. Abstr. 2009). It seems that the selectivity parameter of the shape representation in TE for the reduced visual stimuli is strongly invariant.

To test the existence of Biedermann's theory in ITC, in another preliminary experiment shape selectivity differences were not found in contour deleted, recoverable and unrecoverable stimuli versus line drawing (Sáry et al. Absrt. 1998). To test the neuronal responses for more degraded stimuli, illusory shapes made by abutting gratings were used (Sary et al. 2006). The result of this experiment was compared to the present study about illusory contour. To follow this line I reported two experiments. The first described the processing of Kanizsa illusory shapes; the second discussed the modulation effect of sounds in the TE.

Our experiments give additional information to complete the view of information processing regarding the role of ITC in perception. Everyday experience suggests the holistic way to the representation of the environment. This concept is also supported by the anatomical connections among the different sensory areas.

We found electrophysiological evidence of pure tone effect in a crucial stage of high-level visual perception. We used a simple fixation task, the stimulus had no biological relevance, and thus the modulation seems to have been caused by solely passive information process. But this process is usually not passive; the sensory integration has an essential function in the representation, perception and planning of an action. To perform these tasks the system needs the feed forward information process as well. These connections convert the sensory system 
to an active perceptual system. In the second experiment, we tested the effect of Kanizsa type illusory shape in ITC. These kinds of illusion represent well the active organisation of the information in the early stages of the visual system. However, we gained some results for the rules regarding KIC perception in the more complex area. ITC. They show that the ITC cells need to process the KIC shapes, and they process them in a different way, as compared to shapes with real contours. It seems the ITC is not a passive stage of the visual system; on the contrary, it takes an active part in information processing. 


\section{Acknowledgement}

I would like to thank prof. Benedek György, the former head of the Department of Physiology, and prof. Jancsó Gábor, the present head of the Department who made my work possible in the Institute.

It is a pleasure to thank my supervisor, Sáry Gyula. He supported my work in a number of ways.

I received an excellent training at the Department of Neurophysiology at the KULeuven; I am grateful to prof. Rufin Vogels and Joris Vangeneugden.

I would like to thank my former colleagues, Köteles Károly and Tompa Tamás who helped a lot during the experiments and analysis.

I am grateful to the former and present students: Bognár Anna, Csete Gergő, Csibri Péter, Kincses Bálint, Kis Alexandra, Ferge Petra, Frankó Edit, Nász Veronika, Utassy Györgyi, Varga Zsuzsa.

I also have to thank those colleagues who helped with my administration duties, maintained the experimental setup and took care for the animals: Jász Anikó, Siposné Dósai Gabriella, Hermann Kálmán, Liszli Péter, Rácz László.

I have to thank all my colleagues in the Department of Physiology who provided an excellent atmosphere for my work and all my friends who never failed to help me whenever needed. Finally, my greatest thanks go to my parents. Their support made all these possible. 


\section{Reference List}

1. AKRAMI,A., LIU,Y., TREVES,A. \& JAGADEESH,B. (2009) Converging neuronal activity in inferior temporal cortex during the classification of morphed stimuli. Cereb.Cortex, 19, pp. 760-776.

2. BAUER,R. \& HEINZE,S. (2002) Contour integration in striate cortex. Classic cell responses or cooperative selection? Exp.Brain Res., 147, pp. 145-152.

3. BAYLIS,G.C. \& DRIVER,J. (2001) Shape-coding in IT cells generalizes over contrast and mirror reversal, but not figure-ground reversal. Nat.Neurosci., 4, pp. 937942.

4. BAYLIS,G.C., ROLLS,E.T. \& LEONARD,C.M. (1987) Functional subdivisions of the temporal lobe neocortex. J.Neurosci., 7, pp. 330-342.

5. BERKLEY,M.A., DEBRUYN,B. \& ORBAN,G. (1994) Illusory, motion, and luminance-defined contours interact in the human visual system. Vision Res., 34, pp. 209-216.

6. BIEDERMAN,I. (1987) Recognition-by-components: a theory of human image understanding. Psychol.Rev., 94, pp. 115-147.

7. BOTTGER,D., HERRMANN,C.S. \& VON CRAMON,D.Y. (2002) Amplitude differences of evoked alpha and gamma oscillations in two different age groups. Int.J.Psychophysiol., 45, pp. 245-251.

8. BRODEUR,M., LEPORE,F. \& DEBRUILLE,J.B. (2006) The effect of interpolation and perceptual difficulty on the visual potentials evoked by illusory figures. Brain Res., 1068, pp. 143-150.

9. BRODEUR,M., LEPORE,F., LEPAGE,M., BACON,B.A., JEMEL,B. \& DEBRUILLE,J.B. (2008) Alternative mode of presentation of Kanizsa figures sheds new light on the chronometry of the mechanisms underlying the perception of illusory figures. Neuropsychologia, 46, pp. 554-566.

10. BUCHEL,C., PRICE,C. \& FRISTON,K. (1998) A multimodal language region in the ventral visual pathway. Nature, 394, pp. 274-277.

11. BUDINGER,E., HEIL,P., HESS,A. \& SCHEICH,H. (2006) Multisensory processing via early cortical stages: Connections of the primary auditory cortical field with other sensory systems. Neuroscience, 143, pp. 1065-1083.

12. BULLIER,J. \& HENRY,G.H. (1979) Neural path taken by afferent streams in striate cortex of the cat. J.Neurophysiol., 42, pp. 1264-1270.

13. BURTON,H., SNYDER,A.Z., CONTURO,T.E., AKBUDAK,E., OLLINGER,J.M. \& RAICHLE,M.E. (2002) Adaptive changes in early and late blind: a fMRI study of Braille reading. J.Neurophysiol., 87, pp. 589-607.

14. DEAN,P. (1976) Effects of inferotemporal lesions on the behavior of monkeys. Psychol.Bull., 83, pp. 41-71. 
15. DESIMONE,R., ALBRIGHT,T.D., GROSS,C.G. \& BRUCE,C. (1984) Stimulusselective properties of inferior temporal neurons in the macaque. J.Neurosci., 4, pp. 2051-2062.

16. DESIMONE,R. \& GROSS,C.G. (1979) Visual areas in the temporal cortex of the macaque. Brain Res., 178, pp. 363-380.

17. DICARLO,J.J. \& MAUNSELL,J.H. (2000) Form representation in monkey inferotemporal cortex is virtually unaltered by free viewing. Nat.Neurosci., 3, pp. 814821.

18. DRESP,B. \& BONNET,C. (1995) Subthreshold summation with illusory contours. Vision Res., 35, pp. 1071-1078.

19. EDWARDS,R., XIAO,D., KEYSERS,C., FOLDIAK,P. \& PERRETT,D. (2003) Color sensitivity of cells responsive to complex stimuli in the temporal cortex. J.Neurophysiol., 90, pp. 1245-1256.

20. ELDER,J.H. \& ZUCKER,S.W. (1998) Evidence for boundary-specific grouping. Vision Res., 38, pp. 143-152.

21. FINNEY,E.M., FINE,I. \& DOBKINS,K.R. (2001) Visual stimuli activate auditory cortex in the deaf. Nat.Neurosci., 4, pp. 1171-1173.

22. FISER,J., BERKES,P., ORBAN,G. \& LENGYEL,M. (2010) Statistically optimal perception and learning: from behavior to neural representations. Trends Cogn Sci., 14, pp. 119-130.

23. FUJITA,I., TANAKA,K., ITO,M. \& CHENG,K. (1992) Columns for visual features of objects in monkey inferotemporal cortex. Nature, 360, pp. 343-346.

24. GIVRE,S.J., SCHROEDER,C.E. \& AREZZO,J.C. (1994) Contribution of extrastriate area V4 to the surface-recorded flash VEP in the awake macaque. Vision Res., 34, pp. 415-428.

25. GOODALE,M.A. \& MILNER,A.D. (1992) Separate visual pathways for perception and action. Trends Neurosci., 15, pp. 20-25.

26. GRILL-SPECTOR,K., KOURTZI,Z. \& KANWISHER,N. (2001) The lateral occipital complex and its role in object recognition. Vision Res., 41, pp. 1409-1422.

27. GRILL-SPECTOR,K., KUSHNIR,T., EDELMAN,S., ITZCHAK,Y. \& MALACH,R. (1998) Cue-invariant activation in object-related areas of the human occipital lobe. Neuron, 21, pp. 191-202.

28. GROSOF,D.H., SHAPLEY,R.M. \& HAWKEN,M.J. (1993) Macaque V1 neurons can signal 'illusory' contours. Nature, 365, pp. 550-552.

29. GROSS,C.G., BENDER,D.B. \& ROCHA-MIRANDA,C.E. (1969) Visual receptive fields of neurons in inferotemporal cortex of the monkey. Science, 166, pp. 13031306.

30. HALGREN,E., MENDOLA,J., CHONG,C.D. \& DALE,A.M. (2003) Cortical activation to illusory shapes as measured with magnetoencephalography. Neuroimage., 18, pp. 1001-1009. 
31. HANES,D.P., THOMPSON,K.G. \& SCHALL,J.D. (1995) Relationship of presaccadic activity in frontal eye field and supplementary eye field to saccade initiation in macaque: Poisson spike train analysis. Exp.Brain Res., 103, pp. 85-96.

32. HUBEL,D.H. \& WIESEL,T.N. (1962) Receptive fields, binocular interaction and functional architecture in the cat's visual cortex. J.Physiol, 160, pp. 106-154.

33. HUXLIN,K.R., SAUNDERS,R.C., MARCHIONINI,D., PHAM,H.A. \& MERIGAN,W.H. (2000) Perceptual deficits after lesions of inferotemporal cortex in macaques. Cereb.Cortex, 10, pp. 671-683.

34. IMBER,M.L., SHAPLEY,R.M. \& RUBIN,N. (2005) Differences in real and illusory shape perception revealed by backward masking. Vision Res., 45, pp. 91-102.

35. IWAI,E., AIHARA,T. \& HIKOSAKA,K. (1987) Inferotemporal neurons of the monkey responsive to auditory signal. Brain Res., 410, pp. 121-124.

36. JEFFREYS,D.A. (1996) Simple methods of identifying the independently generated components of scalp-recorded responses evoked by stationary patterns. Exp.Brain Res., 111, pp. 100-112.

37. JUDGE,S.J., RICHMOND,B.J. \& CHU,F.C. (1980) Implantation of magnetic search coils for measurement of eye position: an improved method. Vision Res., 20, pp. 535538.

38. KANIZSA,G. (1976) Subjective contours. Sci.Am., 234, pp. 48-52.

39. KAPADIA,M.K., WESTHEIMER,G. \& GILBERT,C.D. (1999) Dynamics of spatial summation in primary visual cortex of alert monkeys. Proc.Natl.Acad.Sci.U.S.A, 96, pp. 12073-12078.

40. KAPOSVÁRI,P., SÁRY,GY., BENEDEK,GY., TOMPA,T. (2009) Edges and surfaces in the inferior temporal cortex of the macaque-an electrophysiological study (MITT, Budapest, January 22-24, 2009) Abstr., 2009.

41. KASAMATSU,T., POLAT,U., PETTET,M.W. \& NORCIA,A.M. (2001) Colinear facilitation promotes reliability of single-cell responses in cat striate cortex. Exp.Brain Res., 138, pp. 163-172.

42. KOMATSU,H. \& IDEURA,Y. (1993) Relationships between color, shape, and pattern selectivities of neurons in the inferior temporal cortex of the monkey. J.Neurophysiol., 70, pp. 677-694.

43. KOMATSU,H., IDEURA,Y., KAJI,S. \& YAMANE,S. (1992) Color selectivity of neurons in the inferior temporal cortex of the awake macaque monkey. J.Neurosci., 12, pp. 408-424.

44. KOURTZI,Z. \& KANWISHER,N. (2000) Cortical regions involved in perceiving object shape. J.Neurosci., 20, pp. 3310-3318.

45. KOURTZI,Z. \& KANWISHER,N. (2001) Representation of perceived object shape by the human lateral occipital complex. Science, 293, pp. 1506-1509. 
46. KOVACS,G., SARY,G., KOTELES,K., CHADAIDE,Z., TOMPA,T., VOGELS,R. \& BENEDEK,G. (2003) Effects of surface cues on macaque inferior temporal cortical responses. Cereb.Cortex, 13, pp. 178-188.

47. KREIMAN,G., HUNG,C.P., KRASKOV,A., QUIROGA,R.Q., POGGIO,T. \& DICARLO,J.J. (2006) Object selectivity of local field potentials and spikes in the macaque inferior temporal cortex. Neuron, 49, pp. 433-445.

48. KRUGGEL,F., HERRMANN,C.S., WIGGINS,C.J. \& VON CRAMON,D.Y. (2001) Hemodynamic and electroencephalographic responses to illusory figures: recording of the evoked potentials during functional MRI. Neuroimage., 14, pp. 1327-1336.

49. LARSSON,J., AMUNTS,K., GULYAS,B., MALIKOVIC,A., ZILLES,K. \& ROLAND,P.E. (1999) Neuronal correlates of real and illusory contour perception: functional anatomy with PET. Eur.J.Neurosci., 11, pp. 4024-4036.

50. LEE,T.S. (2002) The nature of illusory contour computation. Neuron, 33, pp. 667-668.

51. LEE,T.S. \& NGUYEN,M. (2001) Dynamics of subjective contour formation in the early visual cortex. Proc.Natl.Acad.Sci.U.S.A, 98, pp. 1907-1911.

52. LEGENDY,C.R. \& SALCMAN,M. (1985) Bursts and recurrences of bursts in the spike trains of spontaneously active striate cortex neurons. J.Neurophysiol., 53, pp. 926-939.

53. LI,W., PIECH,V. \& GILBERT,C.D. (2006) Contour saliency in primary visual cortex. Neuron, 50, pp. 951-962.

54. LOGOTHETIS,N.K. \& SHEINBERG,D.L. (1996) Visual object recognition. Annu.Rev.Neurosci., 19, pp. 577-621.

55. MARTUZZI,R., MURRAY,M.M., MICHEL,C.M., THIRAN,J.P., MAEDER,P.P., CLARKE,S. \& MEULI,R.A. (2007) Multisensory interactions within human primary cortices revealed by BOLD dynamics. Cereb.Cortex, 17, pp. 1672-1679.

56. MENDOLA,J.D., DALE,A.M., FISCHL,B., LIU,A.K. \& TOOTELL,R.B. (1999) The representation of illusory and real contours in human cortical visual areas revealed by functional magnetic resonance imaging. J.Neurosci., 19, pp. 8560-8572.

57. MERIGAN,W.H. (1996) Basic visual capacities and shape discrimination after lesions of extrastriate area V4 in macaques. Vis.Neurosci., 13, pp. 51-60.

58. MERIGAN,W.H. \& MAUNSELL,J.H. (1993) How parallel are the primate visual pathways? Annu.Rev.Neurosci., 16, pp. 369-402.

59. MONTASER-KOUHSARI,L., LANDY,M.S., HEEGER,D.J. \& LARSSON,J. (2007) Orientation-selective adaptation to illusory contours in human visual cortex. J.Neurosci., 27, pp. 2186-2195.

60. MURRAY,M.M., FOXE,D.M., JAVITT,D.C. \& FOXE,J.J. (2004) Setting boundaries: brain dynamics of modal and amodal illusory shape completion in humans. J.Neurosci., 24, pp. 6898-6903.

61. MURRAY,M.M., WYLIE,G.R., HIGGINS,B.A., JAVITT,D.C., SCHROEDER,C.E. \& FOXE,J.J. (2002) The spatiotemporal dynamics of illusory contour processing: 
combined high-density electrical mapping, source analysis, and functional magnetic resonance imaging. J.Neurosci., 22, pp. 5055-5073.

62. OLIVA,A. \& SCHYNS,P.G. (1997) Coarse blobs or fine edges? Evidence that information diagnosticity changes the perception of complex visual stimuli. Cognit Psychol, 34, pp. 72-107

63. PARADISO,M.A., SHIMOJO,S. \& NAKAYAMA,K. (1989) Subjective contours, tilt aftereffects, and visual cortical organization. Vision Res., 29, pp. 1205-1213.

64. PAXINOS,G., HUANG,F.X. \& TOGA,A.W. (1999) The Rhesus Monkey Brain in Stereotaxic Coordinates. Academic Press.

65. PEGNA,A.J., KHATEB,A., MURRAY,M.M., LANDIS,T. \& MICHEL,C.M. (2002) Neural processing of illusory and real contours revealed by high-density ERP mapping. Neuroreport, 13, pp. 965-968.

66. PETERHANS,E. \& VON DER HEYDT,R. (1991) Subjective contours--bridging the gap between psychophysics and physiology. Trends Neurosci., 14, pp. 112-119.

67. PIGAREV,I., ALMIRALL,H., PIGAREVA,M.L., BAUTISTA,V., SANCHEZBAHILLO,A., BARCIA,C. \& HERRERO,M.T. (2006) Visceral signals reach visual cortex during slow wave sleep: study in monkeys. Acta Neurobiol.Exp.(Wars.), 66, pp. 69-73.

68. PIGAREV,I.N. (1994) Neurons of visual cortex respond to visceral stimulation during slow wave sleep. Neuroscience, 62, pp. 1237-1243.

69. PILLOW,J. \& RUBIN,N. (2002) Perceptual completion across the vertical meridian and the role of early visual cortex. Neuron, 33, pp. 805-813.

70. POlAT,U., MIZOBE,K., PETTET,M.W., KASAMATSU,T. \& NORCIA,A.M. (1998) Collinear stimuli regulate visual responses depending on cell's contrast threshold. Nature, 391, pp. 580-584.

71. RAJIMEHR,R., MONTASER-KOUHSARI,L. \& AFRAZ,S.R. (2003) Orientationselective adaptation to crowded illusory lines. Perception, 32, pp. 1199-1210.

72. RAMSDEN,B.M., HUNG,C.P. \& ROE,A.W. (2001) Real and illusory contour processing in area $\mathrm{V} 1$ of the primate: a cortical balancing act. Cereb.Cortex, 11, pp. 648-665.

73. RINGACH,D.L. \& SHAPLEY,R. (1996) Spatial and temporal properties of illusory contours and amodal boundary completion. Vision Res., 36, pp. 3037-3050.

74. RINGO,J.L. \& O'NEILL,S.G. (1993) Indirect inputs to ventral temporal cortex of monkey: the influence of unit activity of alerting auditory input, interhemispheric subcortical visual input, reward, and the behavioral response. J.Neurophysiol., 70, pp. 2215-2225.

75. ROCKLAND,K.S., LUND,J.S. \& HUMPHREY,A.L. (1982) Anatomical binding of intrinsic connections in striate cortex of tree shrews (Tupaia glis). J.Comp Neurol., 209, pp. 41-58. 
76. ROLLS,E.T. (2000) Functions of the primate temporal lobe cortical visual areas in invariant visual object and face recognition. Neuron, 27, pp. 205-218.

77. ROUSSELET,G.A., THORPE,S.J. \& FABRE-THORPE,M. (2004) How parallel is visual processing in the ventral pathway? Trends Cogn Sci., 8, pp. 363-370.

78. SALEEM,K.S., SUZUKI,W., TANAKA,K. \& HASHIKAWA,T. (2000) Connections between anterior inferotemporal cortex and superior temporal sulcus regions in the macaque monkey. J.Neurosci., 20, pp. 5083-5101.

79. SARY,G., CHADAIDE,Z., TOMPA,T., KOTELES,K., KOVACS,G. \& BENEDEK,G. (2007) Illusory shape representation in the monkey inferior temporal cortex. Eur.J.Neurosci., 25, pp. 2558-2564.

80. SARY,G., CHADAIDE,Z., TOMPA,T., KOVACS,G., KOTELES,K., BODA,K., RADULY,L. \& BENEDEK,G. (2004) Relationship between stimulus complexity and neuronal activity in the inferotemporal cortex of the macaque monkey. Brain Res.Cogn Brain Res., 22, pp. 1-12.

81. SARY,G., KOTELES,K., CHADAIDE,Z., TOMPA,T. \& BENEDEK,G. (2006) Taskrelated modulation in the monkey inferotemporal cortex. Brain Res., 1121, pp. 76-82.

82. SARY,G., VOGELS,R. \& ORBAN,G.A. (1993) Cue-invariant shape selectivity of macaque inferior temporal neurons. Science, 260, pp. 995-997.

83. SARY, G ., KOVÁCS G., KÖTELES K., BENEDEK G., FISER J., BIEDERMAN L. (1998) Selectivity variations in monkey inferior temporal neurons for intact and contour-deleted line drawings. 28th Annual Meeting for Neuroscience. (Los Angeles, California, November 7-12, 1998.) Soc.Neurosci. Abstr. 24:898, 1998.

84. SCHILLER,P.H. (1996) On the specificity of neurons and visual areas. Behav.Brain Res., 76, pp. 21-35.

85. SEGHIER,M.L. \& VUILLEUMIER,P. (2006) Functional neuroimaging findings on the human perception of illusory contours. Neurosci.Biobehav.Rev., 30, pp. 595-612.

86. SHETH,B.R., SHARMA,J., RAO,S.C. \& SUR,M. (1996) Orientation maps of subjective contours in visual cortex. Science, 274, pp. 2110-2115.

87. SMITH,A.T. \& OVER,R. (1979) Motion aftereffect with subjective contours. Percept.Psychophys., 25, pp. 95-98.

88. SUGASE,Y., YAMANE,S., UENO,S. \& KAWANO,K. (1999) Global and fine information coded by single neurons in the temporal visual cortex. Nature, 400, pp. 869-873.

89. TAMURA,H. \& TANAKA,K. (2001) Visual response properties of cells in the ventral and dorsal parts of the macaque inferotemporal cortex. Cereb.Cortex, 11, pp. 384-399.

90. TANAKA,H., FUJITA,I., KOBATAKE,E., ITO,M., CHENG,K. \& TANAKA,H. (1995) Neuronal mechanisms of object recognition. RIKEN Review, 9, pp. 3-4.

91. TANAKA,H., UKA,T., YOSHIYAMA,K., KATO,M. \& FUJITA,I. (2001) Processing of shape defined by disparity in monkey inferior temporal cortex. J.Neurophysiol., 85, pp. 735-744. 
92. TANAKA,K. (1996) Inferotemporal cortex and object vision. Annu.Rev.Neurosci., 19, pp. 109-139.

93. TANAKA,K. (2003) Columns for complex visual object features in the inferotemporal cortex: clustering of cells with similar but slightly different stimulus selectivities. Cereb.Cortex, 13, pp. 90-99.

94. TANIGAWA,H., WANG,Q. \& FUJITA,I. (2005) Organization of horizontal axons in the inferior temporal cortex and primary visual cortex of the macaque monkey. Cereb.Cortex, 15, pp. 1887-1899.

95. TOMPA,T., SARY,G., CHADAIDE,Z., KOTELES,K., KOVACS,G. \& BENEDEK,G. (2005) Achromatic shape processing in the inferotemporal cortex of the macaque. Neuroreport, 16, pp. 57-61.

96. TSUNODA,K., YAMANE,Y., NISHIZAKI,M. \& TANIFUJI,M. (2001) Complex objects are represented in macaque inferotemporal cortex by the combination of feature columns. Nat.Neurosci., 4, pp. 832-838.

97. UNGERLEIDER,L.G. \& MISHKIN,M. (1982) Two cortical visual systems. In: Analysis of Visual Behaviour (Ed. by David J.Ingle \& Melvyn A.Goodale and Richard J.W.Mansfield), pp. 549-580. The MIT Press, Cambridge, MA.

98. VOGELS,R. \& BIEDERMAN,I. (2002) Effects of illumination intensity and direction on object coding in macaque inferior temporal cortex. Cereb.Cortex, 12, pp. 756-766.

99. VOGELS,R., BIEDERMAN,I., BAR,M. \& LORINCZ,A. (2001) Inferior temporal neurons show greater sensitivity to nonaccidental than to metric shape differences. J.Cogn Neurosci., 13, pp. 444-453.

100. VOGELS,R. \& ORBAN,G.A. (1987) Illusory contour orientation discrimination. Vision Res., 27, pp. 453-467.

101. VON BONIN,G. \& BAILEY,P. (1947) The neocortex of macaca mulata. Urbana.

102. VON DER HEYDT,R., PETERHANS,E. \& BAUMGARTNER,G. (1984) Illusory contours and cortical neuron responses. Science, 224, pp. 1260-1262.

103. WANG,G., TANIFUJI,M. \& TANAKA,K. (1998) Functional architecture in monkey inferotemporal cortex revealed by in vivo optical imaging. Neurosci.Res., 32, pp. 33-46.

104. WATANABE,J. \& IWAI,E. (1991) Neuronal activity in visual, auditory and polysensory areas in the monkey temporal cortex during visual fixation task. Brain Res.Bull., 26, pp. 583-592.

105. WEEKS,R., HORWITZ,B., AZIZ-SULTAN,A., TIAN,B., WESSINGER,C.M., COHEN,L.G., HALLETT,M. \& RAUSCHECKER,J.P. (2000) A positron emission tomographic study of auditory localization in the congenitally blind. J.Neurosci., 20, pp. 2664-2672.

106. WURTZ,R.H. (1969) Comparison of effects of eye movements and stimulus movements on striate cortex neurons of the monkey. J.Neurophysiol., 32, pp. 987-994. 
107. ZHAN,C.A. \& BAKER,C.L., JR. (2008) Critical spatial frequencies for illusory contour processing in early visual cortex. Cereb.Cortex, 18, pp. 1029-1041. 